\title{
Introduction 1942
}

\section{An ongoing struggle with no respite}

In 1942, a fatigued and anxious public was facing a third year of Occupation. The difficulties with which the population had struggled in 1941 continued, but the hardship was all the more brutal and challenging because there was still no visible prospect of it coming to an end. As in 1941, malnutrition and the illness and disease it abetted were rife. Anxiety about finding enough food to eat to stay alive and to stave off serious illness was constant, and, for many, there was the perpetual fear that loved ones from whom they were separated were in harm's way in POW camps or factories in Germany. The Occupation had forced people into compromises and put them under additional pressure in every aspect of their lives. Women were very much on the front line. Many women had to continue to care for elderly and for children and, at the same time, be the family breadwinner in the absence of fathers, husbands and brothers. The period was stagnant and lived very much in the present. Plans to study and to pursue a career often had to be put on hold. The possibility of marrying and starting a family was a remote aspiration for many. The future was determined by circumstances of war which were unpredictable and uncontrollable.

Madeleine's 1942 entries continued broadly in the vein of those of the previous year. Her record still shows that most Parisians were preoccupied with getting through their lives from day-to-day. We get an insight into the extent to which the hardships of the Occupation were forcing Madeleine to forsake her scholarly ambitions. At the outset of the Occupation, Madeleine had been determined to keep studying, but the rising cost of living and the loss of her grant (the bursary had been frozen in 1940) meant that she had to juggle part-time work at the national library, private English lessons, babysitting and caring for elderly invalids. Her doctoral thesis was now less important than securing a degree in English, which would qualify her to teach in French schools in case she was stranded in France indefinitely. There is a very clear sense of how financial pressures on Madeleine preoccupied her and diverted her energies away from her studies. Living alone, she was entirely responsible for her own upkeep and welfare.

The winter of 1942 was harsh and rationing was increasingly stringent. The theme of food - the lack of it and trying to obtain it - becomes even more 
preoccupying for Madeleine. She regularly itemised new rationing restrictions which, on the one hand, may have been a practical 'aide-mémoire' noted down in the same way as she noted down times of appointments, anniversaries and birthdays. But the lists also demonstrate concern, worry, incredulity and anger and betray brittle morale. Food entries also show how the shortages brought people together in new convivial communities based around the pooling of food and sharing of 'work' associated with food, like queuing for it and cooking. Madeleine shared food and the responsibility for cooking it with co-tenants on the top floor of 320 rue St Jacques. Queuing for food which had become a time-consuming burden was also shared between several people. Food shortages also gave rise to innovative systems of exchange. Madeleine would regularly trade private English language tuition for items of food, swap cigarette and wine ration tickets for food tickets and exchange sardines sent to her in Red Cross parcels from Portugal for more varied foodstuffs. People also shared space (and sometimes beds) to economise on heating and lighting and cooking fuel. Thus, a feature of urban living during the Occupation was the transformation of private, personal space into public, shared space which enforced a surrender of privacy. These reformulations were not without tension. Communal living was not to everyone's taste and not all social interaction was positive. Perceptions of unfairness in dealings over food provoked conflict between people discernible in outpourings of anger from Madeleine. Certain personal relationships appeared to be largely transactional; formed simply as a means acquire food but the approach amounted to a collective coping strategy which made even the most desperate weeks of penury liveable.

American publisher Sylvia Beach owned the bookshop and lending-library Shakespeare \& Co in the rue de l'Odéon in Paris. She was famous for having published James Joyce's Ulyssees in 1922 and for the literary community of French and American intellectuals and novelists which grew up around the shop in the inter-war: Joyce, Hemingway, Gide and Simone de Beauvoir were only some of the many illustrious patrons who had made its enviable reputation. ${ }^{153}$ Sylvia Beach had close social links to the student community of the Sorbonne during the Occupation. Although academic attention has largely focussed on Beach's links with the inter-war Paris literati, there is much of interest in the links she had with Paris students and with the female contingent of that community in particular. Madeleine's connection with Sylvia Beach and Shakespeare \& Co was central to her life in Paris and increasingly so, it would appear, from 1942, when references to an intellectual community of women friends she meets through Shakespeare \& Co, book-readings and theatre outings become more frequent. Madeleine was the recipient of moral and financial

${ }^{153}$ These writers were members of the Shakespeare \& Co lending library. Their borrower cards are held in the Sylvia Beach archive at the University of Princeton. 
support from Beach and, judging by the record of the contemporary American and British fiction she borrowed from Beach's bookshop, the recipient of a significant degree of intellectual guidance too.

Shakespeare \& Co was one business of a number of 'scholarly' businesses owned by expatriate American and British women which drew on the University of Paris for their clientele. Mary Niles Maack describes the transatlantic entrepreneurs who set up these businesses as 'bookwomen' who had made Paris their home in the first decades of the twentieth century. Clara Longworth de Chambrun, an American countess and Shakespearean scholar with a doctorate from the Sorbonne ran the American Library. Miss Sarah Watson, who ran the Foyer internationale des Etudiantes and Sylvia Beach who herself had been a student at the Sorbonne were also amongst their number (Maack, 2005). In wartime Paris, it is interesting that networks offering moral and practical support to women students were presided over by British and American women. These kinds of pastoral and intellectual structures were apparent in the early days of women's university education in Britain and the States. In her DPhil 'Claiming an Education: The Transatlantic Performance and Circulation of Intellectual Identities in College Women's Writing, 1870-1900' Jill Lamberton discusses the importance of extra-curricular support offered to these early women students through all-women study, debating and social groups. They were an important source of affirmation in a male-dominated environment where women's presence was not universally encouraged or welcomed.

Madeleine first began to make entries about the books she was borrowing from Sylvia Beach's bookshop and lending library Shakespeare \& Co in 1941. The volume of entries which, on occasion, show her to have read as many as three novels in a single day, support a generally held view that reading was one of the most popular leisure activities during the Occupation. Reading was cheap. Books could be borrowed from libraries and privately owned bookshops like Sylvia Beach's Shakespeare \& Co and Adrienne Monnier's La Maison des amis du livre and, here at least, reading was economically democratic because affordable student subscriptions were available. It was a distraction which could be enjoyed in the relative comfort of one's own home. In other diaries written during the Occupation, those of Jean Guéhenno, Hélène Berr and Geneviève Gennari, books and reading offered psychological respite. They were a distraction from the day-to-day, read sometimes to inspire hope and bolster dissent. Books were censored but censorship proved ineffective in practice. The 'Liste Otto' - a list of banned books drawn up by self-censoring French publishers under pressure from the German authorities - came into force very early in the Occupation in 1940, but Madeleine did not appear to have any difficulty obtaining what she wanted to read. During 1942 she reads voraciously, including banned English titles in both the original and in translation, as well as French writers from the 1920s and 1930s. From the borrower records obtained from Shakespeare \& Co, there is a sense that her reading choices are aligned to the challenges and dilemmas facing young educated women wanting 
careers and financial independence but feeling pressurised to get married and raise children. Writers of the so-called British 'middlebrow' like Rosamond Lehmann, Winifred Holtby and Dorothy L. Sayers, whose novels dealt with conflicts between desire and 'duty' were particularly popular with Madeleine as she contemplated her future.

By 1942, Madeleine began to refer to anti-Semitic repression in relation to Hélène Berr and Françoise Bernheim, young Jewish students who were two of her closest friends. Madeleine had met Bernheim through Sylvia Beach. Like Madeleine, Bernheim had worked part-time in the shop. She had met Berr either through Bernheim and the bookshop or at the Sorbonne where Madeleine had taught as an English language assistant on the undergraduate English degree Berr was taking. Contact between Madeleine and Berr became very frequent when Berr's father was arrested and were especially frequent over the summer of 1942 when the yellow star edict came into force and in the days before and after the Vel d'Hiv round up in July 1942. In 1942, the diary entries about Berr were brimming with love and support and are admiring and sympathetic. When Berr achieved excellent summer examination results Madeleine wrote that Hélène was the cleverest girl she knew and the only people she liked in her life were Freemasons and Jews. It is clear that Madeleine supported Berr. Sometimes Madeleine's entries were cautious, using only initials to denote her Jewish friends - more a feature of later diary entries when both women were in hiding and Madeleine knew where they were. The two women corresponded almost daily while Berr's father was in prison. After his release Madeleine was invited to meet the family at the Berrs' apartment. When, the same night, she disclosed that she was knitting yellow socks and gloves, it is clear that she was doing what many gentile French citizens did by way of a show of support. She was knitting yellow coloured accoutrements to show solidarity with her friends forced to wear the yellow star. Although Hélène talked, in her diary, of feeling isolated and alone as she faced persecution, Madeleine's support of her Jewish friends mirrored the attitude of fellow students and staff at the Sorbonne. Although largely ineffective, there was antagonism about Vichy's anti-Semitic policies within the staff and student body. In 1941 and 1942 there were clashes over the imposition of anti-Semitic programme led by Henri Labroue and disquiet about the introduction of a quota system for Jewish students which limited numbers to $3 \%$ of the student population. In his article 'Léchec du cours antisémite d'Henri Labroue à la Sorbonne (1942-1944)' Claude Singer described how it took time for there to be a stirring of opposition to the persecution of Jewish students and teaching staff but that by the end of 1941 and the spring of 1942, public disquiet over the treatment of Jewish people had grown (Singer, 1993: 3-9). Madeleine was involved in Resistance activities. She had close contact with Resistance leader Georges Auclair and Hélène Barland, administrator in Vichy's Service des monuments historiques, who was 
responsible for counterfeiting documents in the Resistance network Turma Vengeance. ${ }^{154}$ Although there is no firm evidence that Madeleine was involved in protecting Jewish people in Paris, Hélène Berr and Françoise Bernheim certainly did help Jewish children to find safe sanctuary under cover of L'Union générale des israélites de France (UGIF), ${ }^{155}$ where both women worked. By 1942, there is more evidence that Madeleine was becoming a more active opponent of the regime, even if that activity was contained within allusive references in dispersed diary fragments. Even in 1942, Madeleine did not waver from the vow she made in December 1940, namely to keep silent about 'political matters'.

${ }^{154}$ Marc Chantran, Turma Vengeance : Réseau de renseignement - évasion action de la Résistance http://chantran.vengeance.free.fr/ [accessed 4 January 2011].

${ }^{155}$ L'Union générale des israélites de France (UGIF) was set up at the request of the Vichy authorities. 



\section{2}

\section{Thursday 1 January}

Went to Villeparisis. Godfather, Granny, Mme Elizabeth (Deschamps), M. Deschamps and Gérard D, Roger, Aunt V, Yolande, Marcel, me were at lunch. Same for dinner. Played Ludo and Old Maid. ${ }^{156}$ Misty. Aunt has the 'flu.

\section{Friday 2 Jan}

Mlle Koch. Monique didn't come. Ironed. Cut out hood. Sent card to Dédé (and family), Huguette, Simone Pelletier, Zinzer, Paulette Trois-Gros. ${ }^{157}$ Went for dinner at Dil's but had another dinner back here. Read until 1 am (Embury Heath by Stella Gibbons). ${ }^{158}$ Card from Dédé and family.

\section{Saturday 3 Jan}

Bought and took cyclamen to Simone Le Hartel. Card to Vendryès. Waited on Jacques Deschamps for the radio. Fine weather. The sun is rising earlier. Jacques Deschamps came. The radio valve isn't working. Went along with him to the Capoulade ${ }^{159}$ to have a coffee. Rue R. Took back "Mythe et Dieux des Germains" Took out "Les Sociétés Secrètes de Mystères" (O.E.Briem). Very good. Confession. Card from Simone Le Pelletier.

${ }^{156}$ A card game.

157 When Madeleine lists names in this way they are people to whom she has written letters or pneus.

158 Stella Dorothea Gibbons (1902-1989) was a British novelist. Embury Heath was published in 1935. See Rachel Cooke's Guardian piece for more about her life and career:

https://www.theguardian.com/books/2011/aug/07/stella-gibbons-westwoodstarlight-vintage

159 A café on the Boulevard Saint-Michel. 


\section{Sunday 4 Jan}

Mass. Spent the day at Aunt's. J. Deschamps came over. Cafés, restaurants, theatres, picture houses etc shut at $5 \mathrm{pm}$ because of the two bomb attacks (1 German hotel and 1 German bookshop destroyed). Got a new valve for the radio. (I owe Aunt $60 \mathrm{fr}$ for the valve and 430 for the fabric)

\section{Monday 5 Jan}

Went back to the office. Started to have lunch at the hostel again. Started back at the Sorbonne. Waited for Sonia but nothing.

\section{Tuesday 6 Jan}

New "collaborator" for Korbelecky but I don't think that he likes her. Visit from Paulette Trois-Gros. I will have to learn Welsh, but I have eaten too much!!!!!!! (and in times like these!! - but I am eating much better than last year, - and boy, ${ }^{160}$ do I not feel the benefit?). Abbé Falcon speaking on the radio about Breton in schools. Darned.

\section{Wednesday 7 Jan}

Office. Welsh. Rue R.

\section{Thursday 8 Jan}

Mlle Koch paid. No Monique. Colette's birthday. Took nail scissors but no one was home.

\section{Friday 9 Jan}

Welsh. Office.

\section{Saturday 10 Jan}

Office. Darned. Rue R.

\section{Sunday 11 Jan}

Went to Aunt's. She was very catty. "Fille d'Eve". If I don't bring anything, she's catty!! I owe her 500 frs for the fabric and the radio.

\footnotetext{
160 'boy' written in English in the manuscript.
} 


\section{Monday 12 Jan}

Office. Shopping for Korbelecky. Pauphilet. Lesson Mourgeon.

\section{Tuesday 13 Jan}

Office. Darned. Letter and money order Godfather, Granny for tree. Snow.

\section{Wednesday 14 Jan}

Office. Welsh. No rue R. Waited for Jacques Deschamps but he didn't come.

\section{Thursday 15 Jan}

Mlle Koch. Monique paid. Gave eggs, onions, carrots. Rent (reduced because of lack of heating)

\section{Friday 16 Jan}

Welsh. Office. Darned. Got the 150 fr from the money order for the tree.

\section{Saturday 17 Jan}

Office. Darned. Went rue R. but no lesson because they were doing diphtheria vaccinations.

\section{Sunday 18 Jan}

Went to Aunt's. Paid back 100 fr. I still owe her 400 frs. "Face au Destin" Jacques Deschamps there. Was miserable the entire day. Brought cake so there wasn't too much cattiness. ${ }^{161}$

\section{Monday 19 Jan}

Office. Pauphilet. No A. Chenier. Mourgeon.

\section{Tuesday 20 Jan}

Office. Welsh. Rue R. Read "Grey Owl. Récit de la cabane abandonnée” "Ambassadeur des Bêtes". "Un homme et ses bêtes".162

161 'cattiness' written in English.

162 "Grey Owl" was the assumed name of Archibald Belaney (1888-1938), British-born author and conservationist. 


\section{Wednesday 21 Jan}

Office. Welsh. Rute R. Paulette Trois-Gros came over. Snow. Cold. Wrote to Godfather and to Granny. ${ }^{163}$

\section{Thursday 22 Jan}

Mlle Koch. Monique. Snow. Cold. Dil. came. Cold $-9^{\circ}$ at midday!!

\section{Friday 23 Jan}

Welsh. Office. Dil. borrowed my bedroom. ${ }^{164}$ Wrote to Voisin. Andrée Corneil. Hot water.

\section{Saturday 24 Jan}

Office. Did washing. Bought stamps. Thaw. Rue R but didn't get paid. Darned. Pneu from Paulette Trois-Gros about not coming tomorrow. Hooray. ${ }^{165}$

\section{Sunday 25 Jan}

What a beautiful day. Window wide open. Sun. Ate Miss Longhurst's pickled prawns. Wondering if I'll get food poisoning. Not very confident about pickles. We'll see if I get ill. cf. ate bad stuffed olives 13 months ago but fine - no aftermath. ${ }^{166}$

\section{Monday 26 Jan}

Took shoes to be repaired. Put red shoes on. Beautiful. Lots of compliments but my foot hurts!! Took watch back to have glass repaired which has broken again. Office. Pauphilet. A Chénier. Mourgeon. Wrote to Mme Faure. Corbeil. Zéau.

${ }^{163}$ Entries 20th and 21st January have arrows against them in the diary margin to show that their content has been muddled. Madeleine made a correction to the entry of 21 st January, crossing out text and inserting it in the entry of 20th January.

${ }^{164}$ Dilys may have been in involved in Resistance activities. Madeleine may have been lending the room to shelter someone hiding from the authorities.

165 'Hooray' written in English.

166 'no aftermath' written in English in the manuscript. 
Mme Fastier, Uncle at Chateau, Godmother Berthe. Took out “L'Homme à la Bêche" (H. Pourrat). ${ }^{167}$

\section{Tuesday 27 Jan}

Office but holiday because the windows are having draught excluder fitted. Shopping (dates 125 gr, pulses 125 gr). My feet are hurting terribly. Saw Paulette Trois-Gros. Improvised mittens because so cold. Pneu fom André Corneil telling me about a trip out to get vegetables.

\section{Wednesday 28 Jan}

The ice is terrible!!! Got carpeted by Kobelecky because I did not stay on Tuesday. Mme Maréchal brought vegetables. $5^{\circ}$ doing the cataloguing. ${ }^{168}$ The inspector was due to come round but I slipped off for lunch. Went to the Enfants assistés for parcel. Topinambours ${ }^{169}$, carrots, pumpkin!!! (on Tuesday only had pasta to eat - there's nothing to buy anywhere. Bought chicory roots and cooked them with some stock but too bitter. There are no vegetables to be had anywhere. The bread shop is shut. There's no flour. I have porridge for breakfast). Welsh. Breton. Rue R but only Micheline was there. Myriam is ill. My feet hurt a lot. I?

\section{Thursday 29 Jan}

+ Got up late. Mlle Koch. Fine weather. Monique. Red Cross. Ironed. Wrote to Aunt V. Can't get my finances straight. Got the watch back and it wasn't working. Put it on and it works. Took back "L'Homme à la Bêche" annoying. Full of big theories but with nothing to back them up. Visionary without the evidence. Playing the prophet in his toga - but wrong about the facts. Didn't finish reading it. Took out "L'Empire des Serpents" F.G. Carnochan and H.C. Adamson. It's about snake hunters in Africa. Interesting.

167 Henri Pourrat (1887-1959). French writer focussing on rural life in the Auvergne. For more about the writer and his status as an 'official Vichy author' read online: Christian Faure, "Vent de Mars d'Henri Pourrat, Prix Goncourt 1941, ou la consécration d'une ouvre littéraire par le Régime de Vichy", Bulletin du Centre d'Histoire économique et sociale de la région lyonnaise, Lyon, $\mathrm{n}^{\circ} 1,1982$, p. 5-25.

${ }_{168}$ Unclear. Looks like $5^{\circ}$ which might explain why Madeleine slips away early.

169 Otherwise known as Jerusalem artichoke, a root vegetable. 


\section{Friday 30 Jan}

Welsh. Office. Reminded by Ruth about the lesson with Appel. Had dinner at Dilys's with my pasta. Disgusted. ${ }^{170}$

\section{Saturday 31 Jan}

Office. Interviewed Appel. Rue R. Went to Cyla’s

\section{Sunday 1 Feb}

Went to Massy-Verrières. Snow. "Epiphany" "Chapeau Chinois" "Gringoire". Very so-so.

\section{Monday 2 Feb}

Pauphilet. Levaillant. Mourgeon. Snow. Parcel from Corbeil +100 frs

\section{Tuesday 3 Feb}

Office. Monique. Letter from Corbeil

\section{Wednesday 4 Feb}

Office. Welsh. Rue R. Food poisoning from a fish bake. Very ill. ${ }^{171}$

\section{Thursday 5 Feb}

Mlle Koch. Office. Letter from Voirin. Kamska. Letter from Aunt.

\section{Friday 6 Feb}

Office. Welsh

\section{Saturday 7 Feb}

Office. Appel. Snow. Cold. No rue R (sick of this ${ }^{172}$ ). Saw Cyla. Wrote to Corbeil. Went to see Cyla. Letter from Corbeil. No food in Paris.

\footnotetext{
170 'Disgusted' written in English.

171 'ill' written in English.

172 'sick of this' written in English.
} 


\section{Sunday 8 Feb}

Went to see Aunt V. "President Kruger" Huh! Paid Aunt back. No food in Paris.

\section{Monday 9 Feb}

Wrote to Corbeil. Pauphilet. Levaillant. Mourgeon. No food in Paris.

\section{Tuesday 10 Feb}

Office. Monique. No food in Paris.

\section{Wednesday 11 Feb}

Office. Welsh. Sonia came to get the sheets etc. Rue R. No food in Paris.

\section{Thursday 12 Feb}

Mlle Koch. Office. Kamska. Rise in salary ${ }^{173}$ No food in Paris.

\section{Friday 13 Feb}

Vendryès ill. Office. Ruth came to sleep over. Huh! No food in Paris.

\section{Saturday 14 Feb}

Red Cross parents Nov. ${ }^{174}$ Appel. No rue R. Dédé came. Office. First food deliveries of the week.

\section{Sunday 15 Feb}

"Le Bourgeois gentilhomme" with Mlle Koch. Went to Café "La Source" Darned bedsheets until $4 \mathrm{am}$.

\section{Monday 16 Feb}

Red Cross parents 15 Nov. Letter Jeanne Semaille. Mourgeon. Cold. Snow. Dil came. Pauphilet.

\footnotetext{
173 'Rise in salary' written in English.

174 Presumably a letter sent by Madeleine's parents via the Red Cross the previous November. Sometimes mail took months to get through.
} 


\section{Tuesday 17 Feb}

Got a cold. Rue R. (1 hour) Snow. No Monique.

\section{Wednesday 18 Feb}

Office. Welsh. No rue R. Queued for one hour for a kilo of beetroot. Filled out forms for rue de Pressbourg. ${ }^{175}$ Granny's birthday.

\section{Thursday 19 Feb}

Mlle Koch. Office. No Kamska. Wrote to Aunt Violette.

\section{Friday 20 Feb}

Vendryès ill. Office. I need to have a vaccination. Mme Faure came to the office. Met up with her afterwards and had a drink at Etoile. Was invited to her place on the 6th March. Bought [...].

\section{Saturday 21 Feb}

Office. Bought wooden shoes ${ }^{176}$ from Manon. Appel. Rue R. Had vaccination at $2 \mathrm{pm}$.

\section{Sunday 22 Feb}

Godfather's birthday. Icy. Went to Aunt's. Ran from cinema to cinema without getting to see anything. Bored stiff. ${ }^{177}$ I'll go to Aunt's as little as I possibly can in future.

\section{Monday 23 Feb}

Snow. Got up late. Pauphilet. Took back "Grandeur et Décadence des Romains" (Montesquieu). Got out "Le Vin Blanc de la Villette" (Jules Romains). Populist but alive. ${ }^{178}$ Letter from $\mathrm{HB}^{179}$ with a letter from my parents dated 28 January.

\footnotetext{
175 rue de Presbourg.

176 When shoe leather ran out, Parisians were forced to wear shoes with wooden soles.

177 'Bored stiff' written in English and underlined.

178 'alive' written in English.

179 HB is Hélène Berr.
} 


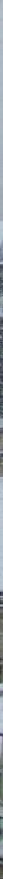

View from 320 rue St Jacques in winter. Copyright Delphine Biechler, licensed under CC BY-NC 4.0.

Had some hot chocolate with Jacqueline Piatier (room 5). ${ }^{180}$ Cold. Darned. [Monsieur Blum dead - note made 25.7.43]

\section{Tuesday 24 Feb}

Office. Monique. Thick snow. Kamska. Depressed. I want my mummy. ${ }^{181}$

\section{Wednesday 25 Feb}

Office. Korbelecky told me that his fiancée had died. Surprised that he had one. Breton. Welsh (there was only Raude and me. Bachellery was disappointed at the low turnout - well it was snowing!) Went to rue R. but the children were not there. Gave the sheets and packing blanket back to Sonia.

180 Room 5 in 320 rue St Jacques.

181 'I want my mummy' written in English. 


\section{Thursday 26 Feb}

Mlle Koch. Snow. Office. Mme (Jacqueline) Maréchal didn't come to the office because sore leg after the vaccination. Mine is like a mosquito bite. Kamska. Wrote to Voirin, Aunt, HB, Godfather, Granny. Got some extra pasta. Just as well because for over a week there has been nothing for sale in Paris. No deliveries. Eating pasta every evening (luckily I had stocked up). A third winter!! Woe. Everything is relative. One day last week: By jove, hot. Went out without a coat, so mild, Spring is here etc etc. $1 \mathrm{pm}$. Still thrilled about the mild weather, winter is over etc. Looked at the thermometer on the Boul'Mich. $-\underline{2}^{\circ} ! ! !$. Granny's birthday. Having bother getting paid at the office.

Bread 275 gr per day. Fat 450 gr per month including 100 oil and 75 marg. Cheese 50 gr a week. Pasta 250 gr a month. Pulse 250 gr a month. Sugar 500 gr per month. Potatoes none. Fresh meat 180 gr per week. Cold meat 90 gr a week. Coffee etc 250 gr a month or 60 gr of tea. Milk, eggs, vegetables etc nothing for the moment. Gas $15 \mathrm{~m}$. cube per month. Electricity $60 \mathrm{kw}$ per month.

\section{Friday 27 Feb}

Vendryès ill. Picked up the patterns - 68 fr a pair!! I'd thought they'd be 24 frs and had ordered two pairs. Only took the one. Office. Mme Maréchal came back. Icy.

\section{Saturday 28 Feb}

Office. Mme Maréchal's last day. Gave her some messages for Dad and Mum. Didn't work much. Korbelecky was all over Mme M. with compliments. Tided the kitchen a little. Appel. Rue R. Took out "Claude" Geneviève Fauconnier. ${ }^{182}$ Great. Marvellous. She thinks like I do. She likes the same things pretty much. Calling frogs "touics" is just lovely. Note to self. Buy it as well as "Sido" (Colette) ${ }^{183}$

\section{Sunday 1 March +}

Went for a stroll. Lovely sun. The snow is melting. Stood leaning against the window, writing. Noises from outside come together with the silence of my bedroom and the pulse of my two alarm clocks, and die. There's the low distant

${ }^{182}$ Geneviève Fauconnier (1886-1969). French writer who won the Prix Fémina for Claude in 1933. See:

http://data.bnf.fr/12147677/genevieve_fauconnier/

183 Sido (1930) is a collection of autobiographical stories by the French novelist Colette (1873-1954):

http://data.bnf.fr/12199028/colette_sido/ 
growl of a barge on the Seine. There's piano playing coming from the building next door. There's the rhythmic grating of a spade clearing the snow. And underneath, there is the soft hum of Paris. Only on evenings of early curfew, before the German patrols, does the humming stop only to start up again little by little. I need to get some more stockings. Those I bought off Mme Fortan are absolutely hopeless - completely crisped up by the dye. I've had them on three times and the net is breaking everywhere. Had hot water so had a "bath".

\section{Monday 2 March}

Sent a pneu to Sonia telling her not to come. Lesson Mlle Rouquette, Pauphilet (2) Levaillant. Mourgeon. The two little girls there are awful. The oldest one doesn't want to learn anything. Mme M. was whining about food. Each time I go, I notice how much the days are getting longer astonishingly quickly. At the beginning, they were pitch black and freezing, then greyish, more lately we've had low sunsets over the snow and today the sun is higher than the Arc de Triomphe. Sonia had been over and left a note. Listened to "Antony et Cléopatra" until midnight. Liked it.

\section{Tuesday 3 March}

Moignard registered me for the Contribuables directes ${ }^{184}$ for the 3000 and some that I got in '41. How nice of him as if I can't think of anything better to do with my money. Letter from Voirin. He seems a little anxious, worried. Sent me 2,000. I expected half of that. I'll put it in the Caisse d'Epargne ${ }^{185}$ because I would like to put at least 6,000 to one side even though money isn't worth anything. I'll be all too pleased to have it if I fall on hard times (anyway, need it to pay Voirin back). Office. Decossin and Uzal report to me. I didn't manage too well telling them to do one thing and then another instead but I didn't know what was what and as Korbelecky says, "tomorrow is another day". Met up with Sonia who is dead set on giving me German lessons. I'm put off. ${ }^{186}$ I don't want to be around her at all. Housework. Beautiful day. Warm sun. Sat on the window ledge for $1 / 2$ an hour.

Read "Claude" in one go. Wasn't blown away by it as I was when dipping in and out of it but I still like it a lot. It isn't obvious that a 40 year old woman wrote it. It is so fresh. - anyway, we stay children all our lives inside. We change on the outside. There is a right way to age. - ie: don't do what one wants to do in public at 30, 40 or even at 20 things that younger people delight in doing.

\footnotetext{
${ }^{184}$ Income tax.

${ }^{185}$ National savings bank set up in the early 19th century to encourage saving among the working classes.

186 'put off' written in English.
} 
Avoid looking ridiculous. Wanting to dance and jump around when one is the size of an elephant is not wrong but just don't do it in public because it looks bad. Ageing gracefully means distinguishing between the interior and exterior and acting in public according to what the exterior expects. Only young people can truly be themselves. Neither frivolity nor seriousness looks out of place in a child. If the exterior is attractive one can be oneself for far longer.

Monique. Hungry. Rue R (1 hour). Mlle Piatier gave me some jam. Finished "Claude". Should have been working but feel too restless. Spring is unsettling me. Very hungry and restless. There's nothing on the radio I like. I'd like to sink into a deep sleep.

\section{$9.45 \mathrm{pm}$}

Was typing up the notes for Welsh with the radio at full blast. The building shook several times. Heard it on the radio. It was like a thunderclap. Went to the window. Planes, flak. Was overjoyed. The caretaker (Mrs Berger), Jacques (her son), a tenant and Miss Fortan and me were flying from window to window to see as much as possible. Smoke trails from flares especially round the Eiffel Tower, South West Paris and five good ones just in front of here. Everybody went to the windows. Planes silhouetted against the clouds. The moon half blotted out. Suddenly just above the Panthéon, 2 light beams and tracer bullets (blue, yellow, red, white), A few bombs maybe? By quarter past eleven things quieten down. Pretty tired. Had a piece of bread and jam (who cares about the bread ration, will try and get more tickets) and finished typing up notes. There were a few more blasts and by quarter to midnight everything was calm. The noise is incredible because it echoes from one hill to another through Paris. Headache now, tired. And so to bed. ${ }^{187}$

\section{Wednesday 4 March}

They say that the air raid alert started at 9.15. It rained all night. At 1.20 in the afternoon the sirens started up. Real or just joking? The road empties in the blink of an eye. Everybody just runs - it's for real then. I took off my coat and shoes. If it is still the same at quarter to two I'll go off to my Welsh class. Got 2,000 francs (two thousand) off Voirin. Shock and horror at the office this morning. M and Mme Somazzi stayed over at friends last night. When they got back in the morning their house was destroyed and their mother dead under the rubble. This was at Boulogne-Billancourt obviously!!! Renault got hit. After the first moments of panic the street has got back to normal. I'm off to class now then.

Cinemas, theatres etc closed today and restaurants shut from 8 pm because the German sentry killed on the rue de Tanger on Sunday 1 March is being buried.

187 'And so to bed' written in English. 
Left for lessons. Was turned back on the rue Soufflot and police insisted that we got to the shelters. But I got back on the Boul'Mich by the rue de l'Abbé de l'Epée which is accessible to pedestrians but not vehicles. Alert over at $2.25 \mathrm{pm}$. Bachellery was late. Lebel and l'abbé Fal'cun even later. Raude and Mme Desportes were there. Went to the rue Mouffetard for food shopping. There were only shallots ( $3 \mathrm{fr}$ ) and cartons of cress ( $7 \mathrm{fr} 50$ !! 14 months ago they were dear at 1 fr 50 but slightly better because they were 10 fr 50 , so I couldn't afford them). Letter from Aunt. Returned "Claude". Got out "Les étangs de la Double" (Geneviève Fauconnier) and read it instead of working. I don't like it as much as I liked "Claude" because it is more novel-like, less about the countryside. But it is good all the same. Wrote to Aunt Violette. Dilys came over.

\section{Thursday 5 March}

$1 \mathrm{~kg}$ carrots. Bought mimosa and violets. Mlle Koch. Office. Mlle Loiret is on work experience. She's nice. I'm now deputy head of the office. Well, well!! Kamska. Made myself up! Everyone thinks that I look pretty with it. I don't. Don't have any envelopes so couldn't send letter to Aunt. Can't find any anywhere. Quite cold.

\section{Friday 6 March}

Lesson with Vendryès. Office. Mlle Loiret came and then left and won't be coming back. Had tea and dinner with Mme Faure. Torrential rain this evening. St Colette.

\section{Saturday 7 March}

Day of national mourning (burial of the Boulogne-Billancourt victims). No office. Got up late. Went to the market but there was nothing. No lunch. St Louis 12.30-1.30 pm. Lesson Kamska. Bought some coquilles St Jacques. ${ }^{188}$ Ate them on the go. Pneu from Aunt who is going to Orgeval. Wanted to buy "Mabinogion" gloves but couldn't. Appel. Rue R. Little Christine Vigot was born at 2 am. Cyla.

\section{Sunday 8 March}

Read late. In the afternoon went to Dilys's and babysat Gaël while Dilys and George went out. Had tea with them and then went to see "Madame

${ }^{188}$ Scallop dish generally made with mushrooms and white wine but can also include other vegetables. 
Sans-Gêne"189 at the Odéon cinema. Read "Grand Meaulnes" (Alain Fournier) and "Turn on the Heat". Went to bed at 2 am.

\section{Monday 9 March}

Got up late. Lesson Pauphilet. Levaillant. Mourgeon. Letter from Mummy. Hooray!! Saw Hélène Berr. Wrote to Aunt. Voirin. Nice day.

\section{Tuesday 10 March}

Office. Registered at the Sorbonne. Monique didn't come. Ruth.

\section{Wednesday 11 March}

Office. Welsh. Read “Malaisée” (Henri Fauconnier). Good.

\section{Thursday 12 March}

Mlle Koch. Office. Kamska. Overtime ${ }^{190}$ at the office. Alert 3-4.30. Went down the shelter because was at the office.

\section{Friday 13 March}

Welsh. Office. Read “Images d'Alain Fournier” (Isabelle Fournier). Not bad.

\section{Saturday 14 March}

Office. Went to the Louvre for cover work but nothing. Bought cactus. Weather fine. Rue R. They'd brought the Vigot baby in. No Appel. Bought gloves and lipstick. Droz bookshop. ${ }^{191}$ Bought "Les Origines du Roman" (Wilmotte). Red Cross, mummy. "Everyone is fine, good news from Nils who hopes that you will go to see his father. Best wishes for the New Year from everyone. Hugs and kisses. Went to Dilys's.

\section{Sunday 15 March}

Kamska. Villeparisis. Lovely day. Hot.

1891925 American silent film starring Gloria Swanson: http://www.silentera.com/PSFL/data/M/MadameSansGene1925.html

190 'Overtime' is written in English in the manuscript.

191 The Librairie Droz, a bookshop and independent publishing house, was founded by Eugénie Droz, a Swiss academic and writer, in 1924. 


\section{Monday 16 March}

Lesson with Rouquette, Pauphilet, Mourgeon. Had some fish. Ruth maketh me sick. ${ }^{192}$ Hungry.

\section{Tuesday 17 March}

Office. Monique. Rue R. $1 \mathrm{~kg}$ of potatoes. At last!! And dates too! Chatted with Madeleine F. Hungry.

\section{Wednesday 18 March}

Office. Welsh. Queued for 2 hours for $1 \mathrm{~kg}$ of carrots. Spotted Cyla. Hungry.

\section{Thursday 19 March}

Mlle Koch, who invited me to Sunday lunch. Office. No Kamska. Hungry. Wrote to Aunt. Letter from Godmother Berthe. Hungry. No sugar. Tired out. ${ }^{193}$

\section{Friday 20 March}

Welsh. Office. Queue for Carrots. Letter from Appel.

\section{Saturday 21 March}

Spring. No Appel. Office. Mourgeon. Bought girdle, bra and a clip. Cyla. Scene between Ruth and Cyla. "Autant emporte le vent" (Margaret Mitchell). ${ }^{194}$ Picked up artichokes from the BN.

\section{Sunday 22 March}

Lunch with Mme and Mlle Koch. Nice change. Ate too much. Went to see "Marius" (Panthéon) and had an ice cream. Read 8.30 pm-9 am.

\section{Monday 23 March}

Went to bed at 9.15 am and got up at midday. Lesson with Pauphilet. Mourgeon. I was asked 4 times for bread tickets (for nothing in return, no meat tickets, no money, no nothing). Feel savage. ${ }^{195}$

\footnotetext{
192 'Maketh me sick' written in English in the manuscript.

193 'Tired out' written in English.

${ }^{194}$ Gone with the Wind (1936) written by American novelist Margaret Mitchell (1900-1949).

195 'Feel savage' written in English in the manuscript.
} 


\section{Tuesday 24 March}

Office. Tired out. Spotted Kamska. "Jettais une petite fille" (Irène Français). ${ }^{196}$

\section{Wednesday 25 March}

Office. Letter from Aunt saying that Berthe is at the hospital Antoine [...]. Lesson. Went to see about going to the ballet at Opéra but it was full. "Valses de Vienne" full. Missed the cinema showing of "Nous les gosses". ${ }^{197} \mathrm{Had}$ a fascinating air raid alert instead. Was pushed back to the Odéon on the Boul'Mich. Was in a shelter on the rue Monsieur le Prince until 12.30. Got back home at $1 \mathrm{am}$. Saw the DCA ${ }^{198}$ in the sky. "Chair de ma chair" (American author).

\section{Thursday 26 March}

Mlle Koch. She gave me a little shawl. Office. Kamska. Went back to see "Nous les Gosses". Another alert but managed to get home. Warm night. Dil came round with a letter in Welsh. "Retour de l'enfant prodigue" (A.Gide).

\section{Friday 27 March}

Welsh. Office. Went to the BN. Got paid. Holiday. Came back on foot. Bought a window box for flowers. Knocked-out. ${ }^{199}$ Went to bed early. "Claudine à Paris" (Colette).

\section{Saturday 28 March}

Got up late. Went to the clinic to see Berthe who has had a breast removed. Was just coming round from the ether. Not a nice sight. Aunt and Yo were there. Appel. Rue R. Kamska. Cyla. Alert. A man was killed in a car at Petit Luxembourg. Tracer bullets are pretty. The chestnut trees are starting to show their leaves.

\section{Sunday 29 March}

Mass. Rameaux. Went to the clinic to see Berthe. Mme Paolotté was there, Berthe's sister in law and nephew. Beer and petits fours with Mme P etc. Berthe

\footnotetext{
${ }^{196}$ Published in 1941.

${ }^{197}$ Nous les gosses was a film directed by Louis Daquin released in 1941. The screenplay was written by Daquin and Marcel Aymé.

${ }^{198}$ DCA is anti-aircraft 'flak. DCA is the French acronym for 'défense contre les aéronefs'.

199 'Knocked-out' written in English in the manuscript.
} 
cheerful and with it. Juniper flowering. Hawthorn is all green. Tired out. ${ }^{200}$ Washed hair. "Les Romanesques" (Jacques Chardonne). ${ }^{201}$ A cloudy and warm day.

\section{Monday 30 March}

Tired out. Got up late. Had a big wash. Spring is tiring me out something rotten. 44 hours behind at work but I'm taking a few days holiday because I am too tired. I feel heavy all over. Went to the clinic to see Berthe. Got my soap (300 gr for two months including $200 \mathrm{gr}$ in bars), my cauliflower ( $1 / 2$ a pound for March), my kg of artichoke. Went to get food ration cards. 20 gr less fat. For bread, it may be that the 350 gr tickets are worthless- meaning that we are only going to be getting 250 gr of bread a day. Appel.

The little yellow juniper bells are weighing down the branches. On the Place Denfert-R there are primulas in flower but no roses. Nearly all the chestnut tree buds have flowered. The avenues are lit up by them. The little flowers of the [...] are set in little bunches against the blue, white - and especially grey - motion of the sky. My hyacinth has opened. It is a beautiful blue-mauve colour but doesn't have much of a scent yet. The crocus have come to nothing. As soon as the hyacinth is finished I'll smash that horrid vase it's in.

\section{Tuesday 31 March}

Sent a message to the Red Cross. Got up late. KO. Went to the Office. Got paid. Bought some soil and some flowers for the window box. Went to Kamska but didn't have a lesson because he was ill. Dinner at Dilys's. Saw Sylvia. Got a photo of Gaël.

\section{Wednesday 1 April}

Got up late. Went to see Berthe at clinic. Brought back the soil I needed. Planted flowers. Did the washing.

\section{Thursday 2 April}

Mlle Koch. 1 pm-7 pm. Went out to the shops with Dilys. Tired out. Drank fizzy wine at Rohan and got slightly "tipsy". 3-4.45 am there was an alert. Poissy (the Mat-Ford factory) bombed. Did ironing. 11 pm-1 am. Alert. Maundy Thursday.

200 'Tired out' in this and the next entry of the 30th March written in English.

201 Jacques Chardonne (1884-1968). French novelist. 


\section{Friday 3 April}

Good Friday. Went to see Berthe at clinic. Invitation Mme Faure for next Friday. Scrubbed floorboards and filled the grooves between.

\section{Saturday 4 April}

Confession. Went to see Berthe at the clinic. Saw Aunt. Yo. Came back on foot with them to Denfert. The plum is flowering (at the bottom). Lesson with Appel (1 hour 1/2) Got paid $150 \mathrm{fr}$ (March and 1 lesson in April). Went to a Milk Bar (Patrick's) for an ice-cream. ${ }^{202}$ Bought an egg for Gaël, sweets, macaroons for Godfather. Listened to the "Damnation de Faust". ${ }^{203}$ Very good. Good singers. Understood it all even the 'chanson de la puce'.

\section{Sunday 5 April}

Easter. Communion. Villeparisis with Aunt, Roger. Godfather's nephew - Jean. Went to the cinema "Narcisse" (already seen it but laughed as much). Yo railed violently against going to confession. So it's Godfather and Granny who had been pushing for a marriage between Yo and Maurice Roche which Yo rejected. Maurice will be getting married in a few days. Went to the "Bois" St Denis. Not a tree left. A lot of anemone. There were violets along the side of the canal smelling good - and the first cowslips. Little white rabbits. Very few trees in blossom. Slept over at Villeparisis (in the morning, had taken an egg to Gaël).

\section{Monday 6 April}

3-5 am. Alert heard at Villeparisis. Saw flowers. Goodrich-Colombes got it. Did some digging. Weeded round the strawberry bushes. Granny gave me 4 eggs.

\section{Tuesday 7 April}

Wrote to Mme Faure. Went to see Berthe at the clinic. Saw her nephew (so flirtatious, goodness me) Went to the BN. Ruth Camp came, because she had come yesterday but I wasn't in. She's up to something, but what? Nothing at the market. Lettuce.

202 'Milk bar' and 'ice cream' in English.

${ }^{203}$ Opera/Cantata written in 1846 by Hector Berlioz. In all likelihood, Madeleine was listening to the performance of the Grand Orchestre de RadioParis conducted by Jean Fournet. 


\section{Wednesday 8 April}

Finished the boards. Went to see Berthe at the clinic. BN. Alert 10.30-12 pm. Nothing.

\section{Thursday 9 April}

Mlle Koch. M (Alexandre). Chabert came to offer me some work. $2 \mathrm{pm}$. Went to collect the translation - I have to look up each word at the moment but it'll probably get easier in a bit. Radishes, cauliflowers, leeks! The image of the proper student - science treatise under one arm, basket full of vegetables, radishes in the other. Head full of dreams. Walked through the Luxembourg gardens. Horse chestnuts ${ }^{204}$ are all flowering. Constantly daydreaming about a little white-washed farm with just a few animals, sunshine, a well. Going to work - so there! ( $\underline{\text { Crinex }}$, for 10 days, finish $18[\ldots]){ }^{205}$

\section{Friday 10 April}

Typed translation. Tea and dinner with Mme Faure. BN. Ruth Camp came over.

\section{Saturday 11 April}

Typed translation and delivered it. Went to Cyla's. Went to the clinic to see Godmother Berthe.

\section{Sunday 12 April}

Mass. Quasimodo. "Marie-Stuart" with Hélène Koch. Had an ice-cream at "The Source"206 Luxembourg with her and her friend. Wore wooden shoes. Aunt Violette's birthday.

\section{Monday 13 April}

Lessons started again at the Sorbonne. Typed translation. Rouquette. Pauphilet.

\section{Tuesday 14 April}

Typed translation. Letter from Monique Vignet (mumps). Letter from Granny. Kamska. Went to the clinic to see Berthe. "La Chatte" (Colette) ${ }^{207}$. Not bad.

\footnotetext{
204 'Horse chestnuts' written in English in the manuscript.

205 Bracketed phrase truncated and abbreviated. Difficult to decipher.

206 Café on the Boulevard St Michel in the 6th arrondissement of Paris.

207 Novella published in 1933.
} 


\section{Wednesday 15 April}

Rent. Office. Bachellery. Typed translation and took it. The young man was sweet. “Trente Arpents" (Ringuet ) ${ }^{208}$. So-so.

\section{Thursday 16 April}

Mlle Koch. Vendryès arrested at 6 am!! Office. Korbelecky came. Typed translation. Dilys came. "Nos Mitrailleuses nont pas tiré"209 (?). Barrage balloons around Paris. Alert $12 \mathrm{pm}-1$ am.

\section{Friday 17 April}

Waited in vain for Vendryès. Found out about his arrest. Read "Desert de Gobi" (P. Benoît). ${ }^{210}$ Very so-so. Office. I? Typed translation. Delivered translation.

\section{Saturday 18 April}

Went to office but not open. Met M and Mme Zéau. Chestnut trees starting to blossom!! Already!! Went to clinic to see Godmother Berthe. Saw Aunt and Yolande. Germans requisitioning cars at Denfert. Appel. Saw Dilys. Had dinner at Cyla's.

\section{Sunday 19 April}

Mass. Bought grape sugar. There's loads of leeks (asparagus are a little dear, 12 and 15 frs a pound). Wrote to Mummy. Feeling good about myself.

\section{Monday 20 April}

Typed translation. Went to the clinic to see Godmother Berthe. Pauphilet. Tired.

${ }^{208}$ Novel published in Quebec 1938.

209 Novel by Jean-Marie Aimot published in 1941. Interestingly, it was based on the French defeat in 1940. He was a collaborationist and a member of Jacques Doriot's Parti Populaire français.

${ }^{210}$ Novel by Pierre Benoit (1886-1962) published in 1941. Benoit was a prolific writer known, according to his biographer Gérard de Cortanze, for novels with erotic undertones framed in exotic contexts. For more on Benoit, see Cortanze's Pierre Benoit (2012) Le romancier paradoxal (Paris: Albin Michel). 


\section{Tuesday 21 April}

Office. Seminar paper. Thought that it was Montesquieu but it wasn't. Monique. Kamska.

\section{Wednesday 22 April}

Office. Welsh etc. Vendryès released. Typed translation.

\section{Thursday 23 April}

Mlle Koch. Office. Bought a little teapot. Godmother left the clinic. Typed the translation. Chestnut trees in flower. Card from Mme Faure on holiday at La Charité. Lilac in flower.

\section{Friday 24 April}

Welsh with Vendryès who looks well. Lost weight. Office. Bought a ticket for the national lottery $\left(\mathrm{N}^{\circ} 33,247\right)$. Delivered the translation. Kamska.

\section{Saturday 25 April}

Office. Got the money off the lottery ticket. Bought another with the money I got back. Went to the clinic but Berthe had gone home. Appel gone home. Letter from Berthe. Pneu from Aunt telling me to buy some dog biscuits for Pataud. ${ }^{211}$ Had to go out again despite my feet killing me. Bought some iris for my garden. The chestnut trees are all out now. All the zinc counters are being replaced with wooden ones. Flappée dead. Cyla.

\section{Sunday 26 April}

Mass. Villeparisis. Hoed strawberry bushes. Lots of lilac everywhere. Brought back big bunches of white and mauve lilac. Sunny.

\section{Monday 27 April}

Rouquette. Pauphilet. Went to Dilys's. She has a swollen neck. Rue R. Fine weather. Torrential rain in the evening. Met Mlle Péchegut who has a poorly

${ }^{211}$ Aunt Violette's dog. Less than a month later, on May 17th, Madeleine writes that Pataud has been put down - probably because there was not enough food to feed him. 
arm. She told me about a cashier job. I wonder whether anything might come of that? Had the egg allowed by the rations (my 3 rd since October). [...]

\section{Tuesday 28 April}

Office. Very windy. "L'Empreinte du Dieu"212 with Mme Fortan.

\section{Wednesday 29 April}

Wrote to Hélène Berr. Office. Welsh. Very windy. York bombed. Invited Jacqueline Piatier and Madeleine Fortan for tea. Housework.

\section{Thursday 30 April}

Wrote to the Red Cross. Mlle Koch (gave me Lily of the Valley). Georges is back. Took lilies to Dilys but she wasn't there (she'd gone to fetch Georges). Nice weather. Windy. 0.10-1.45 am alert. Big fire over Courbevoie (?) way. Gosh, tracer bullets are so very pretty. Difficult to believe that such a pretty fireworks display is sowing death. "La Vie et ses Secrets"213 (Edmond Rostand)

\section{Friday 1 May}

Welsh. Office. Took the lilies to Cyla then stayed too late. "Discours de Bêtes"214 (Colette).

\section{Saturday 2 May}

National Work day today. Stayed in bed. Had lunch at the "Patte d'Oie" with Dilys and Georges. Went to Appel's but wasn't there. Letter from Jean Soulier. Jacqueline Piatier came over at $7.20 \mathrm{pm}$ and talked without stopping once until 10 to midnight. I'd had more than enough. I still gave her a rum and lemon tea whilst wanting to strangle her. Cold. Put the radiator on.

\section{Sunday 3 May}

Mass. Kamska. Went to the flea market but there was nothing. Worked a little. Went to bed early. Beautiful day. Police and militia everywhere in the streets.

2121941 French film directed by Léonide Moguy based on the Goncourt winning 1936 novel by Maxence Van der Meersch.

${ }^{213}$ The attribution of this work to Rostand may be an error as he does not appear to have published anything with this title.

214 This should be Dialogues des bêtes, published in 1930. 


\section{Monday 4 May}

Bought gloves, wooden shoes, Latin dictionary, Lawson and Truffeau. Pauphilet. Went to Hôtel de Ville to see Jean Soulier. I am in huge pain with my foot. Went to rue R but no one there. Fine. "Propos sur le Bonheur" (Alain)

\section{Tuesday 5 May}

Office. Mme Tiffernau started work. I don't like her. She is too indiscreet, her wrists are too fat. Summer is here. Beautiful day. Swotted for exam the whole afternoon. Anxious. Worked until $1 \mathrm{am}$. Alert 11.55 (Crinex $^{215}$ - to the 14th of May inclusive)

\section{Wednesday 6 May}

${ }^{216}$ but the all-clear sirens just went on and on and then started up again. This carry on lasted a good half an hour. Got up early. For a while I have been waking up automatically at $6 \frac{1}{2}$. Office. I don't like Mme T. She is too indiscreet. She rather skilfully grilled the Pedron girl about me. Full of compliments. Feel terribly lazy. Felt as if I was going to fall fast asleep in Breton. What can I do about it? . . . didn't sleep. Went to Appel and phoned. Lesson on Saturday $14 \mathrm{~h} 30$. Got oranges (4). Worked. Tired out. It is warm. For my 'Aucassin et Nicolette' essay: - "in May when the nights are long, serene and silent", - or "warm, silent and serene?" Phew. Hurry now. Off to beddy-byes.

\section{Thursday 7 May}

Mlle Koch. Letter to Hélène Berr. Office. Bought a navy blue jacket. Saw Dilys. Went to Kamska's but not there. Very hot day. Saw Michael. What a bore. Bought blue iris and splendid tulips "Coq de bruyère" bright red with gold edges. Money is going like water. Today 100 frs just like that. Tired out.

\section{Friday 8 May}

Welsh. Office. Rue R. "Jean-Christophe” (1 Vol. "L'Aube")

${ }^{215}$ Crinen or Crinex. A translation commission perhaps?

216 The entry seems to run over from the 5th of May. 


\section{Saturday 9 May}

No office because on holiday. Ill. Sicky. ${ }^{217}$ Appel (paid for April) 11/2 hours. Dad, Mum OK. Bought "Water Babies" for Cyla. "Mariages" (Ch. Plisnier) ${ }^{218}$. Was on the ticket office at Schola Cantorum. ${ }^{219} 14$ people!! - Saw Dilys. Went to see Cyla. Sweet. Row between Cyla and Ruth - about cigarettes. Ate couscous.

\section{Sunday 10 May}

St Jeanne d'Arc. Mass. Pneu from Aunt. Met in Paris. Late. Yolande sulking but still in time for the theatre. Weather bright. We were going to see extracts from various Jeanne d'Arcs at the Palais de Chaillot but it was banned at the last minute. ${ }^{220}$ Saw "Mademoiselle de la Seiglière"221 (Sandeau). Funny. Weather is good. Rue de Rivoli, Tuileries, métro Tuileries shut to the public. Yo sweet. Aunt too. Skirt and 6 eggs. Went to see Aimée. She has a few grey hairs. Victor was there. Very thin. The little girl is fabulous but spoilt. Storm. Ill. (bought cakes for Aunt but ate them).

\section{Monday 11 May}

Prisoners of the Germans at the Val-de-Grâce. Pauphilet. Tired and ill. ${ }^{222}$ Dil came. Wants my bedroom for Wednesday morning. KO. Dog-tired, ill, sicky. ${ }^{223}$ Saw Hélène Berr and Madeleine Lavelle. "Létui de nacre"224 (A. France).

217 'Ill. Sicky' and 'row' later in the entry written in English.

${ }^{218}$ Charles Plisnier (1896-1952) was a Belgian writer and Goncourt winner. A disillusioned Communist, he became a Catholic and established a reputation for novels challenging bourgeois family values. See: https://www.britannica.com/biography/Charles-Plisnier

219 The Schola Cantorium is a private music conservatory founded in 1896, which is still housed on Madeleine's street at 269 rue St Jacques. See: http://schola-cantorum.com/index.php/fr/histoire

${ }^{220}$ Interestingly, Gabriel Jacobs mentions this May 10th performance on page 78 of his chapter 'The Role of Joan of Arc on the Stage of Occupied Paris' in Michael Balfour (2001) Theatre and War: Performance in extremis (Oxford: Berghahn) but does not say that it did not go ahead.

${ }^{221}$ This would be André Antoine's 1921 film of the 1847 novel by Jules Sandeau. See entry in http://www.imdb.com

222 'Tired and ill' written in English.

223 'KO. Dog-tired, ill, sicky' written in English.

${ }^{224}$ A collection of short stories by Anatole France (1844-1924). The 1923 edition is accessible via France's national library digital collections: http://gallica.bnf.fr/ark:/12148/bpt6k229517w 


\section{Tuesday 12 May}

Office. Monique. Rain (I?) Really poorly. Ruth came 8.15 pm. 8.30-11.15 pm. Comforted Ruth. Ruth slept here.

\section{Wednesday 13 May}

Office. Breton. Welsh Bachellery. Rue R. "Berlioz” (Guy de Pourtalès) 225

\section{Thursday 14 May}

Ascension Day. Mass. Mlle Koch didn't come. Ill. Letter from Soulier about a seminar at Ivry but doesn't put the place or the time! Ruth came and took me for lunch to an English restaurant opposite St Julian le Pauvre. Came back with her to study here. What a pain. Dil came and we went to the Closerie des Lilas. Kamska. Ill.

\section{Friday 15 May}

Welsh. Sick as a dog. Nausea [. . .] etc, etc. office. Went by the Hôtel de Ville to find out the time of the seminar. Got back KO. Wanted to go to bed because had an awful migraine but Ruth came over to have another cry. "I feel so humble; I kneel before the eternal Mother in you [sic]. And then blubs. I am too ill to kick her out and I let her carry on crying in my arms. Kisses, more kisses. After an hour of that she finally left. I don't want her here again. It is definitely unhealthy. ${ }^{226} \mathrm{Had}$ an aspirin in a bowl of lemon tea. Temperature all through the night. Cyla no longer goes to the hospital. Mme Scarpazza is dead.

\section{Saturday 16 May}

Office. Doctor Bossin-Legros about Nico. ${ }^{227}$ I have the organs of a little girl!! If I don't look after myself - no children. Damn!! The madwoman in the attic is out. Prepared to do anything even have an illegitimate child by a lover. But this morning (Sunday) after a good night I decided that it'd all be OK with injections etc and if I will it to be so. But I didn't think it was as serious as

${ }^{225}$ For more about Swiss novelist Guy de Pourtalès (1881-1941) see the archive entry at the University of Lausanne:

https://www.unil.ch/crlr/fr/home/menuinst/fonds-darchives/guy-depourtales-1881-1941.html

and the website of the Foundation Guy Pourtalès:

https://guydepourtales.ch/

226 'Definitely unhealthy' written in English.

227 Nico short for Nicodème, which is how Madeleine refers to her menstrual cycle. 
that. Like a little girl!!! I'll reach puberty after I'm married. How lovely! But back to the diary. Was leaving for the docs and the lift comes back up with Ruth. "You're off somewhere?", "Aha" "Where?" "Doctor's" "Let me stay in your room this afternoon" (and what a look!!) "No you can't" "Why not?" "It is in a mess" "Oh I don't mind" "No, I don't want you to. It's an unimaginable mess" "Ah, I see" (another look!! She sees what exactly?). She tags along with me to Denfert-Rochereau, telling me about her knickers which are slipping down and then, because I am monosyllabic, wants to know why I am going to the doctor. "Women's problems" "But what? Don't you want to talk to me about them?". "Sweetheart" (shades of Quin who would call us sweetheart when she was furious with us) "Why? You can't cure me" "Oh, but ... describe your symptoms to me" (that look is back). "I don't have any - that's the problem" (the look is well and truly back) "I see." And then she's off talking about her own experiences etc. Why have I just written all that which reads like a page of Colette minus the style? I don't normally note down anything in this diary now because of nosy parkers. (Phew!!228 the thought of Ruth in my bedroom and this book hanging around!! Argh! 7.45. I need to get myself up. Need to finish quickly. Went to Ivry. The countryside is like Yorkshire near Wakefield with the road sloping down etc and stone walls and the rain coming down. Was on the ticket desk for "les Mystères de Paris" (by Eugène Sue) by Renaud. ${ }^{229}$ Helped by a nice chap. Dropped by Dilys's. Late evening she came by here, drank tea and chatted. She is sweet. ${ }^{230}$ Goodnight.

\section{Sunday 17 May}

Woke up at 6 am. Superb weather. Did Latin translation and wrote diary, did everything in bed which explains the writing. Mass. Missed the train for Villeparisis but met Aunt in tears in the station because Mme Scarpazza is dead. She is really upset about that. Now, she is really worried about Yolande's health. I talked about myself and shouldn't have done. I needed some reassurance and some kindness but AV told me that the doctors didn't know what they were talking about and whilst she didn't say that I was an idiot in so many words, it was clear by her tone. Oh, she was too upset about Mme Scarpazza and was worried about Yolande. No one else is allowed to be ill. Yolande and Roger arrived on Saturday evening at Villeparisis. Yo looked awful, ashen with circles round her eyes. Godfather was very, very thin. In a fortnight he has just wasted away. He hasn't enough to eat. He's used to having lots. Pataud has been put down. I don't know when. It's probably best. He was starving to death. Studied (well, I made out that I was reading). Yo was having hot flushes etc. It's not

228 'Phew!!' written in English in the manuscript.

${ }^{229}$ Possibly a theatre adaptation of Eugène Sue's 1842 novel.

230 'nice' and 'sweet' written in English in this entry. 
nice, obviously and obviously when she's with the family she can behave how she likes but I really felt like slapping her. I said my piece - she wasn't unpleasant but she thinks that I am stupid. Only Granny could relate to me properly. The atmosphere over there is depressing. Perhaps I am hyper-sensitive but I didn't feel good. It's daft. I really should know that I am not allowed to be ill nor to come over more than twice without bringing anything. When I bring something they are nice. They make me take something away - eggs, a skirt etc. If I come empty-handed - Good God, I'm in the way like a piece of furniture. Anyway, I can't complain. I left Aunt (what would my life had been like if I had stayed with her). But when I think that the girls on my landing are kinder to me than they are there (with the exception of Godfather and Godmother), well!! It's funny. Lots of whispering going on between them all about next weekend with Yo and it's "Shush, here's Madeleine" when I come in from the garden. I've got good hearing. Yolande is off to the Opéra-Comique on Saturday and then probably on to Orgeval afterwards. So what? I can go out without asking their permission. But what a load of creeping about and when I think that for 3 months they've been coming out with the same old "No one is hiding anything. Everyone knows everything". I could see it then and I see it now!! The Sunday before, Aunt had been so nice. I had thought that it would last - but moods don't last. I'm a slow learner. What other grievances do I have while I'm moaning on and lancing the boil? Well, it does help saying it and writing it down. I must be twice as careful to make sure that this book doesn't fall into the wrong hands. What a waste of effort it is not saying anything for months on end just so that if there is an accident nothing comes out. Oh well. Never mind!!

Usually, I find it funny when I hear "Life is so hard, coming back after work, having to get food in, housework too. And Yo hasn't enough to eat. She's only got her rations you know!!! No meat. We save it up for Sunday" (not quite true). They are forgetting to mention the monthly parcel and the Black Market. They are forgetting ... but it doesn't matter to them that I am on my own too in respect of finding food and that I too have only got my card. Oh well anyway. Yo pulled out of her exam. Too tired (I've got nothing to do though of course).

\section{Monday 18 May}

Had a big revelation!!! Of course, why didn't I think of it before!! Last Sunday Yolande asked me how much I was earning. I told her the truth (I didn't say anything about my pay rise). Crikey me, from $460 \mathrm{fr}$ to $1,273 \mathrm{fr}$ is a big leap!! Yo told me that she was getting 1,600 frs which is probably around 1,450 frs. She must have said all this to Aunt which explains absolutely everything. Ah Nanère, you reckon you're a psychologist and that's the one thing you forget!! There'll also be a question mark over inheritance if I don't have kids. But, steady on. I'm not yet infertile and I will do my best not to be. But if I am, I will adopt kids.

I love this apartment - the same me who couldn't stand it before. When I came home wounded and depressed yesterday evening it was like bathing in 
joy and optimism as soon as soon as I opened the door. It is time to get up. It is 9 o'clock. Beautiful sunshine (and rotten writing - yes, indeed. I'm lying on my back and this book is heavy to hold). They treat Godfather and Roger in the same off-hand way they treat me. I wonder if that hurts them at times. Granny started a lace crochet for a blanket for me. It is very pretty and she is kind.

PS: What a misery guts I am! Everyone has problems. Granny with Riri who is now just a labourer and who can't wear the uniform after having been kicked out of the fire service. There's Aunt with Yo who she can't marry off etc. Hey get up!!231 Mlle Rouquette. Went to Hôtel de Ville to take the ticket receipts. What a beautiful day. Ruth - what a letter she's sent me!! Is she mad? Female homosexual? Or does she just want to make herself appear interesting? Bought flowers for Mme Scarpazza and took them to Aimée who is not at all devastated, horrified nor helpless as Aunt had led me to believe. Pauphilet. I am avoiding Ruth. Went to the Société des gens de Lettres to get paid. Went to Dilys to get her advice about Ruth's letter. She thinks it's funny - luckily!! I fear I lack a sense of humour. Appel (1 $1 \frac{1 / 2}{2}$ hours) Kamska. Bought a pound of cherries. What an oppressive heat! Going to write to Ruth and send her back her letter.

\section{Tuesday 19 May}

Dilys came early. Office. Wrote to Ruth and posted letter at $9 \mathrm{am}$. Noticed that although $\mathrm{R}$ had put Friday evening as the date, posted it after having seen me on the Saturday which proves that she hasn't an ounce of spontaneity about her. There a new "collaborator" in the office. Cleaned from top to bottom. Monique. Injections still not arrived. 57 (fifty seven) francs for rubber soles for wooden shoes. Christ almighty. Bought another pound of cherries - and I realise that I have not enough money to last me until the end of the month. I bought a heavenly rose - the red is so dark that it looks black in certain lights. I really must get myself a crystal vase for the roses. Went to Dilys's to babysit her kid from $7.30-10.15 \mathrm{pm}$. Found out that Rudi and Sonia have been arrested. I have no energy for working. Got a message from mummy via the Red Cross: "In excellent health. Nils, family his five colleagues send best wishes, received news from Hélène, Madeleine. Daddy is still collecting stamps. Try to send more news. More news!! Ye Gods. ${ }^{232}$ How? I can see myself writing: "Pretty poorly because Nicodème doesn't come" or "Very tired but I am looking after myself". God, mummy would imagine me dead or at best on my death bed surrounded by a bunch of doctors. Or else I could write: "I bought a new pair of glasses" - then they would think it was some sort of new code at the German Red Cross. I'll

231 'Hey get up' written in English in the manuscript.

232 'Ye Gods' written in English in the manuscript. 
sleep on it. I'll wake up with fresh ideas. Ruth came over when I was out and put a message under the door: "Came over to catch up" I have been avoiding her for two days and I have been expecting her to turn up. Did she get the letter? Tomorrow I will not be able to avoid her I fear. I am hungry. Shall I go to bed or shall I eat something? I daren't touch my 100 grams of bread for tomorrow, nor the rice. I've got nothing. I think I'll nibble a carrot.

\section{Wednesday 20 May}

Office. Welsh with Bachellery. Mme Desportes brought me a little bit of full cream milk. Ruth. Gale and violent rainstorm. My cacti are going to flower!! Can't get over it. Got news from Mummy sent in March. "The lack of news doesn't mean that there is anything to worry about. We are all fine and everything is good generally. Well done on the exam. When will you finish? Much love from us and the gang." 233

\section{Thursday 21 May}

Cleaned from top to bottom. Mlle Koch. Wrote to Godfather, Granny. Showers.

\section{Friday 22 May}

Welsh. Office. Appel (1 hour)

\section{Saturday 23 May}

Office. Ticket desk at 10 Rue de Lancry for 14.30 (because Soulier told me so) but the performance was on at $17 \mathrm{~h}$. Note from Cyla saying that she had gone camping. Ruth came. Made a bit of a scene but I didn't play along.

\section{Sunday 24 May}

Pentecost. Mass. Villeparisis. Saw “Gueule d'Amour” with Jean Gabin. Rubbish.

\section{Monday 25 May}

Went to Kamska's. Not there. Studied

${ }^{233}$ Written in the margin opposite the entry of 20th May: 'No, the cactus isn't flowering. It's just new branches. 4-6-42.' 


\section{Tuesday 26 May}

Did some mending. Dylis ${ }^{234}$ came to get me up. Françoise Boësse brought 3 eggs and stayed 3 hours. Cyla came to do the injection. Went to Dilys who made strawberry tarts. Got a pneu from Auclair. Letter from Mme Fauchier-Delavigne.

\section{Wednesday 27 May}

Office. Saw Cyla in the street. Went to rue R but not there. Period. Completely infertile. All I want to do is sleep. Feel sick. ${ }^{235}$ My head is swimming. I can't work. I can't study.

\section{Thursday 28 May}

Koch. Cold. Office. 6-7 pm went with George Auclair to "La Source". He wants to know what I am made of. Much good may it do him!! Got tomatoes. Went to Cyla's for injection.

\section{Friday 29 May}

Welsh. Ill. Office. "La Mort" by Maeterlinck. Appel (1 hour) Went to the jardin des Gobelins . Pretty. Full of trees.

\section{Saturday 30 May}

1.15-3.45 am. Alert (but sounded at $2.30 \mathrm{am}$ ). Thought that it was a storm. Office. Telephoned rue Las Cases - not there. Tifferneau took me for lunch and tried to get me drunk. Very sleepy. Went to do the tickets at Trocadéro but didn't stay long. No vegetables or fruit anywhere. Saw Cyla in the evening. Did my own injection. Cyla, Zeila, Sonia sang in Russian. Lovely.

\section{Sunday 31 May}

Mother's Day. Bought flowers and cake. Villeparisis. Rain. Ill. Went to "Marie Stuart". Yo gives me the impression that she's taking stimulants the way she laughs, shouts and races round. She has a nice "swing" figure. She needs a husband I think. Aunt was nice.

\footnotetext{
234 'Dylis' is a misspelling of Dilys.
}

235 'Feel sick' written in English. 


\section{Monday 1 June}

Start of month abundance - butter, bread, cheese. Fine and warm. Ill. ${ }^{236}$ Can't study. KO. Appel ( 1 h 30). Out of the blue at $19 \mathrm{~h}$ felt a sense of well-being, felt joyful. Went to Cyla's. Did my own injection. Cyla was revolted but calmed down soon after. Ruth called me to unburden her heart etc. Since Cyla rejected her she needs a pole to wrap herself around. I call her the 'creeper' but it's not wrong. I picture her as a green snake with loads of red mottling (her tail is attached somewhere but I can't see it) and the head lifts and falls and tries to come after me (tree trunk lathered in oil). What a strange recurring vision to have when I think of her. It's like thinking of Ravel's 'Bolero' every time I think of Simone Noëlle - when I used to see her way back when or even when she was there and I didn't know she was. The exams are the 17 th or the 18 th. I feel happy. I think that Ruth wanted caresses but I laughed it off and was whizzing around like a Catherine wheel and so it was impossible to create a romantic atmosphere. She hates that she can't just shack up with someone - what's her problem if that's what she wants?

\section{Tuesday 2 June}

Office. Monique (who brought me 4 eggs, some potatoes and onions) Studied Balzac (Ernst-Robert Curtius). ${ }^{237} \mathrm{Had}$ an uneasy feeling that Ruth was going to come. I am determined not to let her intrude upon me here at home. Hot.

\section{Wednesday 3 June}

Hot. Office. Met Ruth who wants me to ask Cyla if Cyla will invite her to go on holiday with her. I said that I would ask her to avoid a scene in the street but it is up to Cyla what she does. My thoughts are blooming furiously [. . .]. I'll have a pretty bouquet by this evening to put in front of Mummy's photo. Hot. Met Dilys. Welsh. All the cats are on their backs in the sun, striking adorable poses. Graceful and sweet, their arms in the air like children sleeping soundly in the heat. Went to Cyla's for the last injection of this course. I'll go back next Wednesday. Zeila and Cyla very depressed at first but later perked up. There was a row between Zeila, Cyla and Ruth about margarine. Ruth got me to go to her place afterwards. Me, me, me!!! She tried the big seduction scene and had washed in scented soap, put on a very low cut dress, the reading lamp was very low, I was in bright light and she was a blurry silhouette in the shadows. After a few whimpers, she came to kneel down in front of me and played around

\footnotetext{
236 'Ill' written in English in the manuscript.

${ }^{237}$ Ernst-Robert Curtius (1886-1956) was a German literary critic and philologist.
} 
with her dress, letting it slip over her shoulders as low as she decently could, watching me intently like a cat. I found all this carry-on hilarious. It was like being in the presence of a fat squashy maggot. Certainly as repulsive. She got going with her carry-on and trembling with desire squeezed my feet between her hands and then quickly adopted a praying pose - and then we got the prayer. I laughed in her face. Even she could see that I didn't like it: "Your face is so tight. What are you thinking of?"238 She went on about wanting to know what I was thinking. All my "love interests" have done the same when things are going off the boil. They are insistent that I tell them what I am thinking just like her or rather she does like them. She behaves like a man in love. She's a funny girl. She is as materialist as it is possible to be and then makes out that she is an idealist. What she needs is a man. I left in the end. "Ah, kiss me, kiss me" I pecked her on both cheeks. 239 "No, no more than that". Annoyed, wanting to see how far she would push me to tell her some home-truths "You want me to do the great rough lover?" ${ }^{40}$ I caught hold of her roughly and planted a kiss near her ear and then I set her straight again. She put her hands on my shoulders and kissed my cheek with a drowning cat expression on her face. Should I have gathered my skirts and fled saying "Fine, if you want to be a homosexual but count me out". Don't know. I make as if I don't notice. She'll never get anything from me. I won't be able to show this book to anyone else I don't think. But things fade so quickly. What about all those quirky personalities at the Pension. ${ }^{241}$ I didn't set them down and they become indistinct so quickly. Ruth wants to leave for Zone libre $e^{242}$ and to her great disappointment I am encouraging her. Studied until 1.30 am but didn't get to sleep until around $3.45 \mathrm{am}$. There was a quarter moon, orange and not bright. Got up at $3 \mathrm{am}$ and put on the radio but could only find Russian (or Polish or Slav). Took off a blanket. Slept well. Rue R.

\section{Thursday 4 June}

It is going to be really, really, really warm. Bunches of ideas for my "garden". Mlle Koch brought brooch and biscuits. Office.

238 'Your face is so tight. What are you thinking of?' written in English in the manuscript.

239 'kiss me, kiss me' and 'pecked' written in English in the manuscript.

240 'home-truths' and 'You want me to do the great rough lover?' written in English in the manuscript.

241 This is a reference to Madeleine's co-lodgers at Les Marronniers boarding house, where she lived during the Phoney War, November 1939 to June 1940.

${ }^{242}$ The Free 'unoccupied' zone in southern France governed - ostensibly - by the French Vichy authorities. 


\section{Friday 5 June}

Welsh. Office. Appel (1 1/2 hours). Hot.

\section{Saturday 6 June}

Office. Kamska. Did the tickets Bd. Barbès. Went to Hélène Koch's to meet her brother. Ruth came but I wasn't here. Hooray. Hot.

\section{Sunday 7 June}

Went to Aunt's. She lent me photos. Took a walk with Yo in the new park and at the Buttes Chaumont. Ruth came but I wasn't here. The Jews have got to wear a yellow star. ${ }^{243}$ Jacques had a little boy a few days ago.

\section{Monday 8 June}

Studied. Washed hair. Appel (11/2 hours)

\section{Tuesday 9 June}

+ Office. The weather is fresher. Monique.

\section{Wednesday 10 June}

Cold. Insides all mashed up; hacking cough. Not an unpleasant feeling!!! Welsh. Rue R. Cyla. Injection. Office.

\section{Thursday 11 June}

In the bread that we get at the hostel there is everything one might wish for bran, straw, sawdust, worms. The bread at my bakers is just about edible. Kamska. Office.

\section{Friday 12 June}

Office. Appel (1 $1 \frac{1}{2}$ hours). Last lesson.

\section{Saturday 13 June}

Office. Pneu from Mme Faure. Talk at avenue Ed. Vaillant, Pantin. Storm. Went to Mme Faure's. News from Mummy. "Darling, don't worry yourself. Everything

${ }^{243}$ From Sunday 7th June 1942 the German authorities decreed that Jews had to wear the Yellow Star in France. 
is fine. Everyone is in good health. Dad is doing his gardening as usual and he sorts out his stamps for relaxation. There are two apple trees behind the house. The little courtyard is just the same. Topsy has a three day old son. I had my teeth seen to. I'll be having to have false teeth one of these days. Aunt Germaine, Gilberte and everyone are in good health. All of us send you all our love. Mummy." Went to Dilys's place. Mrs Evans's birthday.

\section{Sunday 14 June}

Went to Villeparisis. Ate strawberries and raspberries until I could eat no more. Every time I go there I swear that I will never go back but I do. Everything Aunt says is designed to hurt but deep down and despite everything I do love her. In the end, though, I have decided to go "live my life" - family or no family. Brought back beautiful roses. Ruth came over but I was not in.

\section{Monday 15 June}

Library was not open. Pity. Swotted here.

\section{Tuesday 16 June}

Swotted. Talk ${ }^{244}$ with Adrienne Monnier ${ }^{245}$ about modern poetry. Not much said but as I left I felt that I could rule the world.

\section{Wednesday 17 June}

Swotted. ${ }^{246}$ Knitted. 1.30-6 pm. Classical literature, French composition. "To what extent is it true to say that the doctrine 'art for art's sake' is already discernible in the 'Bucoliques" by Chénier?” I think that I did alright but the plan was "wonkey" 247 and repetitive. Writing awful. It was funny but I had a feeling that the subject would come up and so went in with a few ideas. Hope I don't fail it. Hélène Berr got a commendation for her diploma. She is the most intelligent girl I know. For the Latin unseen translation they were allowed dictionaries! And what next?? A fair copy?? I can't get over it! I'll set off tomorrow with

\footnotetext{
244 'Talk' written in English in the manuscript.

245 Adrienne Monnier was a bookseller and publisher and proprietor of the bookshop and lending library La Maison des amis des livres. She was also Sylvia Beach's life partner, which may have been how Madeleine made her acquaintance.

246 'Swot' written in Engish.

247 'Wonkey' (sic) written in English.
} 
my big fat Gaffiot ${ }^{248}$ under my arm. Why is it that the only good souls around me are Quakers or Jews? Tired out after the exam. 9-11. Went for a walk. Ruth came but I was out.

\section{Thursday 18 June}

8-12 am. Did Latin translation. A real Chinese puzzle. I think that it went $\mathrm{OK}$ in the end. Saw Madeleine Lavelle. Tired out. Bought "Cent phrases pour éventails" (Claudel) 249 "Enfantines (Valery Larbaud) ${ }^{250}$, "Le Piéton de Paris" (Léon-Paul Fargue). ${ }^{251}$ Read "Les Haïkaï de Kikakou!” All delightful. Flappie. Went to Dil's. She has a new maid, Françoise. Went to Elizabeth's. Superb studio flat. She is a designer. Had dinner with Dilys. Dilys came over to mine.

\section{Friday 19 June}

Mlle Koch. Brought me some flowers. Did the housework. Aching all over and KO. Office. Went to Cyla's. Read "La Fille du Capitaine Pipe"252 and "Les Chakras".

\section{Saturday 20 June}

Office. Weather was fine. Tired out. Ruth came over. Danced between 9-11 pm. She wanted to be the weeping willow again but I didn't encourage it. She is after me.

\section{Sunday 21 June}

Tired out. Went to the market and got two artichokes. Money just goes like its nothing. I should spend $200 \mathrm{fr}$ a week. I've spent 400. Expenditure I haven't bargained for is fatal for the budget. What am I going to do this summer? Did some embroidery. Finished the handkerchief. Deep depression. ${ }^{253}$ Cried and then felt happy. Started the ankle socks again.

\footnotetext{
${ }^{248}$ Gaffiot is a Latin-French dictionary first published in 1934.

249 Poetry collection by Paul Claudel (1868-1955) published in 1942.

250 Valery Larbaud (1881-1957). Enfantines Published in 1918.

${ }^{251}$ Léon-Paul Fargue (1876-1947). For more on Fargue and Le Piéton de Paris see:

http://republique-des-lettres.com/fargue-pieton-9782824903057.php

${ }^{252}$ Written by Simone Saint-Clair and Juliette Lermina-Flandre La Fille $d u$ capitaine Pipe was published in 1941.

253 'Deep depression' written in English.
} 


\section{Monday 22 June}

Office. The blue [...] dress went down a storm. Why? Didn't get any cigarettes. Wrote off for extract from birth certificate. Mme Faure. H. Berr. Dropped a note to Cyla. Got up. Ironed. Did the washing at $3 \mathrm{pm}$ and by $7.30 \mathrm{pm}$ everything had been ironed. Bought some stamps for Dad - got some for 140 frs!! (and I ask myself where the money goes?). Typed [...]. Welsh. Wept. ${ }^{254}$ But then was happy afterwards and for the rest of the day. Is it a sign of getting right? Of the nerves getting back to normal? Or is it a bad sign? I think that it's no more than a sign of extreme fatigue. Fine and warm since yesterday. There is no food to be had. Potatoes with tickets only. That is all I am living on. Got some milky substance and some cheese without tickets last weekend thankfully!!

\section{Tuesday 23 June}

Office. Last lesson with Monique. Took cigarettes over to Cyla's Wrote to Aunt.

\section{Wednesday 24 June}

Office. Welsh. Last lesson at Rue R. Letter from Mme Faure, Hélène B.

\section{Thursday 25 June}

Mlle Koch. Cyla came. Went to Boissin-Legros' place. Chic! I feel better. Got some medicine. Went to Mme Faure's. Wrote to Hélène B.

\section{Friday 26 June}

Went to the Welfare Bureau. Office. Went to Cyla's for an injection. Read "Crime en Australie". Ruth tried to bewitch me again and wanted me to stay the night. Christ almighty! How awful!! Refused point blank. Went to Dilys's but only her mother was there.

\section{Saturday 27 June}

Office. Letter from Aunt telling me that Granny had an operation for a strangulated hernia on Tuesday. Poor woman. She has been through such a lot in life! Confession. Slept most of the afternoon. Hope that the storm gets on and happens. I've felt on edge all day. The nap calmed me down a bit. Had to queue for an hour to get some peaches. Horribly tense. Ate at least a pound of peaches on the way back. I feel agitated, angry. I don't want to work. I don't want to do anything. What is in the air?

254 'Wept' written in English. 


\section{Sunday 28 June}

Mass. Sick as a dog. Stomach ache. Thumping migraine. And I am as anxious as all Hell. Read "L'Eternel mari" by Dostoïevski. Was on the ticket kiosk at Boul. Barbès and went to the talk on "Folk-lore de L'T̂le de France" Nice. Wrote Aunt Violette and went to Cyla's. Wanted to get back quickly because was feeling ill and weary but Cyla made me stay, made me sing, brightened me up. She sang.

\section{Monday 29 June}

Office. Ill. Waves of pain coming from the stomach. Telephoned Aunt. Granny has got over the operation well. Finished the washing. Cyla gave me an injection. Went to the Atelier to see "Sylvie et le Fantôme"255 with Mad. Fortan. I've not laughed as much since "Pygmalion". Didn't have dinner. Mass. St Pierre and St Paul.

\section{Tuesday 30 June}

Fine. Ill. Argued with Stella Tifferneau. Have got to go back in to get pay. Read "Fin de Chérie" (Colette). Had an ice cream with Stella T at Weber's. So expensive!! Both tiny. Too dear. Won't be doing that again. Went to Cyla's for injection. Very offended that I couldn't stay to have dinner because I had a lesson with M. Koch. She didn't believe me. Didn't have dinner. Lesson with Mme Koch. Had a fruit juice with her at "La Source". Sick as a dog. Mme Desportes came but I didn't open the door to her.

\section{Wednesday 1 July}

Office. Ill. Hot. Went to Cyla's and she said that it is my appendix and that I shouldn't wait until I have a third attack of appendicitis. Went to Mme Desportes. She was very nice. Went to Dilys's who sorted me an appointment with her doctor - woe! Big storm. 1 yoghurt and 1 cracker for dinner. Tasted like ash. Went to bed early. Took an aspirin.

\section{Thursday 2 July}

Mme Koch. It's warm and close. I feel slightly better but weak and heavy; feel like I've been at death's door. Slept. Went to Hélène Berr's. Huge storm. Read "Nez de Cuir"256 (? ). ${ }^{257}$

${ }^{255}$ Play produced by André Barsacq at his theatre l' Atelier in Paris.

${ }^{256}$ By Jean de la Varende. Published in 1936.

${ }^{257}$ Gap and question mark in the manuscript. 


\section{Friday 3 July}

Office. Ruth got her exam. The results were not up. Slept until midday and feel better, Dilys came read "La Vagabonde" (Colette) ${ }^{258}$ and "Le Noeud de Vipères"259 (Mauriac).

\section{Saturday 4 July}

Office but left early. Telephoned Aunt. Letter from Aunt. A Mlle Blaise passed. Me? Not me? Not me. I've failed. Strange but I am fine about it. Very relaxed and cheerful. I should be unhappy but I am not. Am happy. Why? Saw Ruth who is all confident about her oral exam. She gave me some little cakes and then said, rather condescendingly, that she would come to see me when I am at Cyla's. But got to Cyla's and Cyla was irritated and Ruth didn't come. Brilliant. Cyla is fed up - her bike was stolen last Wednesday, etc. Went to Dr Cusin's with Dilys. He diagnosed appendicitis too. I'll have to have an operation. Wants me to go to the clinic. Read "Nous avons fait un beau voyage" (Francis de Croisset). ${ }^{260}$

\section{Sunday 5 July}

Got up at $5.30 \mathrm{am}$. Waited for Françoise who didn't show. Went to Denfert and found her there. Couldn't go by bus. Had to take métro and bus. What joy to see the countryside again. Great big fields of corn, green flecked with gold and solitary trees, dark green and standing deep in the corn. ${ }^{261}$ Roses and clematis everywhere. It's such a delight to see cows again - I nearly jumped up onto my seat in the bus, pointing at them with my finger, yelling "Look, cows". Baby. Villages, big farms like towns in MA surrounded by high walls. At Bligny I saw Georges. So much for my plans to go walking in the countryside!! Georges latched on to me and wouldn't let go. It is the first visit he has had for a year. Dilys doesn't go any more. Death stalks this Sanatorium. It is horrible. It is pretty though. There are the woods, the coastal pines with their red trunks against dark green, there's the pond. It's even worse as far as the women go; these young misses with their parasols and their fixed smiles like in adverts! Terrible!! Had lunch at Brice [Brüsse? (Brüce)] Came back from the Bligny sanatorium. Dying in the heat. Went to Dilys to take her a letter, $\mathrm{M}$ and Mme Bachellery were there and they couldn't believe that I hadn't passed my exam. Georges wrote complimentary things about me; Dilys visibly narked. Stayed to dinner. The wounded

\footnotetext{
258 Sidonie-Gabrielle Colette (1873-1954). Published in 1910.

259 François Mauriac (1885-1970). Published in 1932.

${ }^{260}$ Francis de Croisset (1937-1937). French-born playwright. For a digital copy, see: http://gallica.bnf.fr/ark:/12148/bpt6k5452390d.r=.langFR

261 'in the corn' written in English.
} 
returned having waved the white flag. Ruth didn't pass her exam. Read "Féerie Cinghalaise" (Francis de Croisset). ${ }^{262}$

\section{Monday 6 July}

Office. Failed Latin with a 6, French with a 7. Declared my identity card lost. Telephoned Aunt - who spoke to me like I was an idiot because of appendicitis.

\section{Tuesday 7 July}

Office. Slept. Mlle Koch. Went to "La Source". Read "Le Film de ma Vie"263 (Lefèbvre).

\section{Wednesday 8 July}

Office. Read "Un Rude Hiver"264 (Raymond Queneau). Made myself something to eat. Welsh. Knitted. Dil called over for me to go out with her. Went to Sylvia's and then to Dr Duheim's to get some glasses. He has a beautiful black spaniel, Mayou, "Prince of Darkness". ${ }^{265}$ Dr D is a radiographer and yachtman. ${ }^{266}$ Handsome old man. Beautiful apartment. Had Kirsch and petits fours. Mrs Evans ill. Dilys is so eminently selfish. She knew that I hadn't had dinner - oh you poor darling, oh you poor dear $-{ }^{267}$ but she didn't invite me back for dinner or shorten her walk, Her mother is very ill. Oh, you poor dear, but she goes on about her [.. . $]^{268}$ without a second thought. And what about Georges? He hasn't had a visit now for a year is it? She also boot licks the rich and steps over the poor. Knows that I haven't got any money at the moment but is being very sweet because she wants something no doubt. But what friend, what human being is perfect? She's my friend, even with all these faults.

\section{Thursday 9 July}

Mlle Koch. Did my washing watched by a soldier at the Val-de-Grâce opposite. They must find it tedious watching what their neighbours are doing opposite.

${ }^{262}$ Published by Hachette in 1935. See full scan of the work in French national library digital collections: http://gallica.bnf.fr/ark:/12148/bpt6k58126108

${ }^{263}$ Written by René Lefèvre. Published in 1940.

264 Novel published in 1939.

265 'Prince of Darkness' written in English.

266 'yachtman' written in English.

267 'ill', 'selfish', 'oh you poor darling, oh you poor dear' written in English.

${ }^{268}$ Looks like 'verres' (glasses) in manuscript but that would seem incongruous. 
Write to Aunt and to the Tax Office. I am trying my very best to make sure that I don't spend more than I have in the bank. Went to the Red Cross and sent: "Got the message from Paul. Congratulations to Topsy. Granny had a successful operation for a hernia. Everyone here is well. Look after yourselves. Kisses! Went to see Vendryès about the meal. Read "Le Mystère de la Charité de Jeanne d'Arc" (Péguy) Welsh. Went to Cyla's. Ruth was annoying me and to get rid of her I said "Oh, everyone knows that you love Cyla" - ! A huge storm is brewing.

\section{Friday 10 July}

Washed. Ironed. Office. Dilys cancelled going to the Bachellerys. Went to the Police about the identity card. Saw Michael who said to me "So you see, I'm doing what you wanted and not seeing you". I said "That's just fine. Carry on like that and it'll be perfect”. Letter from Hélène. Letter Mme Faure.

\section{Saturday 11 July}

Office. Knitted. Welsh. Read "Chéri"269(Colette) and "The Man who had Everything” (Louis Bromfield). ${ }^{270}$

\section{Sunday 12 July}

Mass. Welsh. Knitted. Wrote half a story. News from Mummy written 1/6/42: "We are all fine still. We had 8 days off and made the most of them. Uncle Tom did a few repairs at Aunt Marguerite's who has been a little poorly but don't worry. She is much better but like all of us isn't getting any younger. Francis is going to get married in a couple of months to a school friend from the same year group. Doggywoggy has a little playmate; a little black cat with a white patch called Niki. Jeanne is their nanny. Kisses to everyone."

\section{Monday 13 July}

Office. Physical exercise. "Goodness gracious" as Korbelecky would say. Sumptuous meal at mine - fish, peas and potatoes. Read "Houtekiet" (Gérard Walschap). ${ }^{271}$ Welsh.

${ }^{269}$ Published in 1920, a novel about a romantic relationship between an older woman and a younger man. Colette was one of Madeleine's favourite novelists.

270 The Man who Had Everything was published in 1935. Brief biographical details about Louis Bromfield (1896-1956) can be found at http://www.ohiohistorycentral.org/index.php?title=Louis_Bromfield\&rec $=52$

${ }^{271}$ Gerard Walschap (1898-1989) was a Belgian writer. Houtekiet was published in 1939. The most fulsome biographical information about him 


\section{Tuesday 14 July}

Pneu to Mme Koch. Did physical exercise. Went to Versailles to the Bachellerys with Dilys. Dilys and B did a lot of talking. Went to the Parc de Versailles. Saw and smelt the orange blossom for the first time ever. Came back. Had dinner at Dilys's. Got a note from Mlle Jorges.

\section{Wednesday 15 July}

Office. Telephoned Aunt. Typed story. Mlle Jorges came. Physical exercise.

\section{Thursday 16 July}

Wrote to Hélène Berr. Mlle Jorges and Mlle Koch. Went to the BN. Russian and Polish Jews 27,000-40,000 according to rumours. Where have they been taken? ${ }^{272}$ Went to Ruth's and to Dilys's. Wrote to Mme Faure and Mummy. "Katherine Mansfield and Me" (H. Middleton-Murray). ${ }^{273}$ Depressed. Physical exercise.

\section{Friday 17 July}

Physical exercise. Mme Jorges. BN. Office. Horribly depressed. Ill. Read "The Road" by Warwick Deeping ${ }^{274}$ and "J'ai tué un homme" (Maurice Rostand). ${ }^{275}$

appears to be contained within a Wikipedia entry at:

https://en.wikipedia.org/wiki/Gerard_Walschap

272 This is a reference to the infamous Vel d'Hiv round-up of Jews in Paris over the 16 th and 17th of July 1942. More about the Vel d'Hiv round-up can be found on the website of Yad Vashem, The World Holocaust Remembrance Center: http://www.yadvashem.org/yv/en/holocaust/france/vel_dhiv_roundup.asp

273 Either an edition of the letters exchanged between Katherine Mansfield (1888-1923) and lover John Middleton-Murray (1889-1957) or an edition of Mansfield's diary. For more on the life of Murray, see:

http://spartacus-educational.com/Jmurry.htm

${ }^{274}$ George Warwick Deeping (1877-1950) was an English writer. See Mary Grover's entry in The Literary Encyclopedia for more information on his life and career: Mary Grover 'Warwick Deeping. The Literary Encyclopedia. [https://www.litencyc.com/php/speople.php?rec=true\&UID=1199]

275 Maurice Rostand (1891-1968) was a French novelist and the son of poet and dramatist Edmond Rostand (1868-1918). The title of his novel appears to be incorrect in Madeleine's entry. Rather, it should be L'Homme que jai tué. The novel was published in 1921. 


\section{Saturday 18 July}

Office. BN. Went to confession. Nothing to say but just wanted to hear the sound of a human voice. Sick, ill tired, ${ }^{276}$ terribly depressed. "Roi des Montagnes" (About). ${ }^{277}$ Pneu from Aunt telling me not to come tomorrow.

\section{Sunday 19 July}

Mass. Sick and tired. Am no longer able to tell myself stories. The only story: getting home. Terribly lonesome. Worked on thesis all afternoon. Feel better, happier.

\section{Monday 20 July}

St Marguerite Wrote to Aunt, Granny. BN. Saw Ruth when I went to buy the meal tickets. She feels important and tries to hurt me. She is completely sadistic. With a gleeful, sadistic look she tries to discern evidence of pain. I hope that she is happy because I am not remotely suffering. Remark from Ruth: "The young girl who collects the tickets must have such sharp hearing to have discerned my English accent. So sharp". Good heavens!! You'd have to be deaf not to hear it!! No Mme Koch. "Fin de Chéri" (Colette).

\section{Tuesday 21 July}

Office. BN. Saw Ruth at St Louis. She is trying to hurt me. What on earth is the matter with her? I said that I would like to go to see Cyla before Saturday and she pulled a "gleeful sadist" face. Maybe she thinks that she has found the weakness in my armour. She hasn't yet. "Message actuel de l'Inde" (Les Cahiers du Sud). ${ }^{278}$ Wrote Dr Cuzin, Bachellery, Mlle Jorges.

\section{Wednesday 22 July}

St Madeleine. Gave Madeleine Fortan some roses. Office. BN.

\section{Thursday 23 July}

BN. Letter from Mlle Piatier. Saw Ruth. Went to the Grande Madeleine. Cyla. Cyla was difficult. She thinks I look ill. Mlle Koch. Then I went with her to "La

276 'Sick, ill tired' written in English.

277 Published 1897.

${ }^{278}$ Les Cahiers $d u$ Sud was a French literary journal founded in 1925 by Jean Ballard. For more on the history of the journal see Alain Paire's 2004 history of the journal, Chronique des Cahiers du sud, 1914-1966 (Paris: IMEC). 
Source" to meet her fiancé. He is ugly and speaks French very badly. Mlle Koch fell out with her mother a month ago now.

\section{Friday 24 July}

Mlle Jorges. Got a card from Aunt. Office. Tired out ${ }^{279}$ because I was up at 6.30 am because I couldn't sleep. Took back "Messages actuels de l'Inde" without getting past the Introduction because I was too tired to take anything in. "La Naissance du Jour" (Colette). ${ }^{280}$ Gosh. Like me, she needs to be suffering to write. I also understand why she writes about the things she does. It's to get them out of her system ${ }^{281}$ so that they don't haunt her - like with Ruth. Sido, Colette's mother says something very true. "We can only be happy by wanting and not by having".

This evening there was a gorgeous sky - turning from blue to a faded green silk with long plumes of liquid gold spreading out in a fan shape towards the West; "ruffled" plumes. ${ }^{282}$ The swallows chirping way up high. The church bells ringing out softly. The sun's red glow is reflected onto a single window in the Val-de Grâce. The moon, which is almost full, is high in the sky. Read by moonlight alone, leaning up against the window until $10.45 \mathrm{pm}$. Couldn't sleep.

\section{Saturday 25 July}

Woke up at $6 \mathrm{am}$. Went back to sleep. Was determined to. Too tired to get into this bad habit. Woke up at 7 am with a headache. Well done. Didn't do exercises. Too stiff. Office. Went to Dilys's. Bought sweets. Stepfather. Did the washing 3-8 pm. Cyla came. Knitted. The heat is heavy and overpowering.

\section{Sunday 26 July}

Mass. Went for a walk around Luxembourg. Villeparisis. Aunt very sweet. Brought back first apples of the season. Cherries. Beetroot, peaches, roses and daisies.

\section{Monday 27 July}

Got up at $6.30 \mathrm{am}$. Did the ironing. Physical exercise. Office. Ironed. Darned. Mlle Koch brought two beautiful roses, 1 red dahlia, some daisies. Wrote to Mlle Piatier. Very windy. "aventures quotidiennes" (Colette)

\footnotetext{
279 'Tired out' written in English.

${ }^{280}$ Published in 1928.

281 'It's to get them out of her system' written in English.

282 'ruffled' written in English.
} 


\section{Tuesday 28 July}

Office. "Mme Colette" (Gonzague Truc). ${ }^{283}$ Did washing. Slept.

\section{Wednesday 29 July}

Office. "Mes apprentissages" (Colette). I'm getting a real thing about Colette. She's really great this woman. What a lot she has been through. Cyla came over with Zeila. Went to Cyla's. Saw Sylvia. Brought back bottles, clothes hangers etc. I’ve only got 40 c left!! Saw SS again. Read "Mystérieux No1".

\section{Thursday 30 July}

Neither Mlle Koch nor Mlles Jorges came!! Office. Darned. Went to Dilys's. Gaël is lovely. [...]. And she really loves me. She gives me hugs. Did the washing. "Les Vrilles de la Vigne" - Colette.

\section{Friday 31 July}

Mlle Jorges came. Went to Dilys. Tided everything away. Put things in a suitcase. Saw Ruth - things are not going well between her and Cyla. Went with Cyla to the atelier. ${ }^{284}$ Goodbye meal with her and "Curlylocks". She kissed me before leaving. Oh! It hurts so much that she is leaving. Said goodbye to Mad. Fortan.

\section{Saturday 1 August}

Took the train from Luxembourg at $7.50 \mathrm{am}$. St Rémy at 8.40. Waited for the bus until 10.45!!! Brawl to get onto the bus for Fonteney-sous. Got off at Briis and went on foot to Mulleron. $2 \mathrm{~km}$ ? Pretty views. They were cutting the corn by hand. Only saw two women reapers. It's pretty hilly in patches. ${ }^{285}$ Wooded hills. Pretty butterflies, yellows, blues, reds. Emperor butterflies, those dark velvety ones with the black streaks? It is hot but not overly. Was not expected for lunch but had some. Black pudding, beef stew, jam, bread, wine, coffee, eau-de-vie. Rested in bedroom. Note to self: Remember to thank Ruth for the sweets. Went for a walk. Lay under the trees. Hot. Pretty view. Blackberries. Went to the woods. Two planes collided mid-air and fell out of the sky.

${ }^{283}$ Gonzague Truc (1877-1972) was a French literary critic.

284 Théâtre de l'atelier.

285 'patches' written in English. 


\section{Sunday 2 August}

Mass at Petit Fontainebleau. Saw Georges. Slept. [. . .]. Saw Georges. Ate blackberries in the valley.

\section{Monday 3 August}

Wrote to Aunt. Zinger. Stole plums.

\section{Tuesday 4 August}

Went for a walk. Saw Georges. Went down the valley.

\section{Wednesday 5 August}

Went to Janvry. Pouring down here. Then went to La Vallée picking up what I could on the way.

\section{Thursday 6 August}

Did some gleaning. ${ }^{286}$ Went to see Georges.

\section{Friday 7 August}

Did some gleaning. Knitted. Very tired. Wrote to Godfather and Granny. Mlle Péchegut

\section{Saturday 8 August}

Went to Fontenay-les. Briis. Saw a marriage. Went to Briis-sous-Forges. Bought a book from Evelyne.

\section{Sunday 9 August}

Switched rooms. Beautiful room over the hills. Mass at Fontenay. Went to see Georges. Read "la Fille du Puisatier" ( $)^{287}$ Jacqueline Haubre and her mother came.

286 This means picking over fields for any vegetables left behind after the crops have been harvested.

287 Brackets blank in manuscript. Written by Marcel Pagnol (1895-1974) and published in 1941. The film of the book, produced and directed by Pagnol, came out the year before in 1940 . 


\section{Monday 10 August}

Chantecoq. Went gleaning

\section{Tuesday 11 August}

Went fishing.

\section{Wednesday 12 August}

Chantecoq. Lost myself in the Charmeuse woods in the afternoon. Lovely butterflies!!

\section{Thursday 13 August}

The Guillemots have gone. Went to the Sanatorium to see Georges and Dilys and Gaël. Went to Janvry, Chantecoq, virtually as far as Gometz-la-Ville, La Brosse, Janvry. Saw a crashed plane. Tired out. $14 \mathrm{~km}$ in one afternoon.

\section{Friday 14 August}

Tired out. Knitted. Played 'Submarines'. Mother and Father nursemaids came. Ill all night. Madeleine Fortan’s birthday.

\section{Saturday 15 August}

Mass at Fontenay. Quite poorly. Knitted. Cloudy day.

\section{Sunday 16 August}

Mass at Janvry. Back to Paris. Very hot and close. Got the keys from Dilys and saw Sylvia. Letter from Mme Desportes - dated 29 July!! Gas leak. Didn't see Georges at the Sana. At Janvry the sky is "matonne" (moutonné), ${ }^{288}$ la chouette "gueule"289; one gets a "coquin"290 ( un amoureux); "je suis été"; 291 "On se "goberge"292

${ }^{288}$ Sky full of little white clouds like sheep. It is interpreted as a sign of rain to come.

289 Une chouette can mean a little owl. Here its seems to also be a variation on 'gueule' which can be a slang term for face used at Janvry.

${ }^{290}$ Could mean rascal or rogue here.

${ }^{291}$ Incorrect conjugation of être in perfect tense. Not clear what Madeleine is getting at here. Possibly she is mocking improper usage or alluding to language play engaged in with friends at Janvry.

292 Pamper oneself. 


\section{Monday 17 August}

Toilets are leaking. Flood! Got a valve for the gas. Did the housework. Went to the office to borrow 500 francs. Returned the money to Dilys who is being very cold with me. She is only nice to me when she needs me or sense that I have some money. Am going to gently drop her. Wrote to Mme Desportes. Paris is airless. Unpacked bags.

\section{Tuesday 18 August}

I am 24 years old. I feel younger now than I did a year ago - or even two years ago. Wrote to Gillemot, Viala, Godfather and Granny. Got lunch book. Bought flowers from the barrow. 8 frs wasted because they are withered. Washing. Darned. Very hot. A little canary came to see me - cheeky like a sparrow. He sings prettily.

\section{Wednesday 19 August}

Started exercising again. Tidied all the food together and put the box under the radio. I have a spare chair. Spent an hour at Mlle Péchegut's. When I got back I noticed that I didn't have my food card. Did I lose it or did Viala not give me it back? It really is worrying me more than I want to admit. Read "Jules de Corneillan" (Colette) whilst eating tomatoes, apples and sugar. Unhappy and bored to tears. Ironed. Heavy. There's probably going to be a storm. I can't find "La Terre qui meurt" by René Bazin anywhere. I am bored - bored, bored - and I am too hot. I sweat making the slightest movement. My toilet isn't repaired yet. I don't feel as if I can do any housework. Everything is such an effort. If only it would break with a storm. Dil came to hear the news. Raid - or landings? At Dieppe. Nine hours later, they left. Dilys came to talk to me about Georges. I acted not bothered and she felt reassured. She probably needs me at the moment because she's offering to do favours and paying me compliments about everything. Huge storm. Lots of sheet lightning. ${ }^{293}$ It looks strange - right in the middle of the storm, rain, flashes, thunder and the moon there shining away. Silvery reflections coming off the wet roofs and the bright fringes of clouds containing the storm itself. Feel in a better mood.

293 'sheet lightning' written in English in the manuscript. 


\section{Thursday 20 August}

Wrote to Aunt. Went to the market, Tomatoes Can't make pickles because I only have ground salt and I need powdered salt. Darned.

\section{Friday 21 August}

Tidied papers. Letter to Granny, Aunt. Got a young persons' work prospectus for Germany. There was a message from the Red Cross but it wasn't for me. Wrote to Mme Faure and Voirin "Duo" (Colette). Cleaned the toilet and the kitchen. Tired out. Looked for the food card at Dilys's. Knitted.

\section{Saturday 22 August}

Dad's birthday. Finished tidying the kitchen. Got a letter from Hélène Berr. Saw Ruth twice. Message from mummy "Darling. Everything is still fine here. Thoughts are with everyone and especially with you. Don't you worry about us. Everything is fine. Aunt Marguerite is ageing a bit; she acts old. Aunt Cardines's brother died. The rest of the family is well. I went to the school and they all want to be remembered fondly to you. Gérald and Agnès died following accidents. Loving thoughts and kisses to everyone. Cuddles from Toutou. I forgot to tell you that the lilac has flowered this year" 20/7/42. Pneu from Aunt telling me not to come tomorrow. Good. Confession and cross-examination from the priest. I didn't like it at all. Bought one cauliflower. Two tickets for green beans ( $1 \mathrm{~kg}$ in total), radishes. I've got tickets for $\underline{340}$ grams of meat. I have never seen as much. Misty and cold. "L'Envers du Music-Hall" (Colette).

\section{Sunday 23 August}

Mass. Communion. Knitted. Fine. "Le Toutonnier" (Colette)

\section{Monday 24 August}

Mass. Communion. Washing. Ruth came over. Went to the cemetery at St Denis. Had a shock when I saw the grave. It looks impoverished and poorly maintained. Decision made. I should come every month. That is more than I do. Resolved to come and maintain it. Mummy would like that. The return journey was never-ending. Y had put out some evil smelling gypsophila and dahlias. Went to the BN. Did the ironing.

\section{Tuesday 25 August}

Card from Cyla. Letter from Hélène Koch. Got food card. Helped Ruth send off the chests. BN. Ruth came and then got me to go to her place to get the table 
and then decided that no - she just wanted me to talk to her, etc. Resolved to see her as little as possible. St Louis. Mass. C. "Contes" by Maupassant. ${ }^{294}$ Duke of Kent killed in a plane crash. ${ }^{295}$

\section{Wednesday 26 August}

Mass. C. Washed hair. Beautiful hot day. Moved the table out with Ruth. BN. Got card from Mme Faure. Queue for tomatoes. "Salute to Adventurers" (J. Buchan). ${ }^{296}$

\section{Thursday 27 August}

Mass. C. Blessing. Miss Beach came while I was darning sheets. 9.10-10.30. She is sweet. Had lunch at 10.30 am but wasn't hungry!! Telephoned office. We won't be paid before Saturday, unfortunately! BN. Went on foot to Mme Faure's because am completely broke. Waited from 5.30 until 6.30 then left inviting them to call round on Saturday.

\section{Friday 28 August}

Mass. C. Did curtains. It takes ages. Madeleine Fortan came back Gave me 1 tomato, 2 carrots, 1 clove of garlic, parsley and tarragon. Talked until 3 am. Warm. Close. Chatted with Mlle Péchegut.

\section{Saturday 29 August}

Can't do my exercises. I feel too stiff. Went to the office. Made up all the time I owed. Got things ready for Mme Faure. Bought some honey. Put the curtains up in the bedroom. Didn't want them at first because I thought that black curtains would be more original. But once they were up was happy. They look pretty and cheerful. Bought pink and white coloured carnations. Nobody came. Something probably came up. Got some news from Mummy dated 27 July. "Darling. Thank you for your news of the 19th. We are fine and we are happy to

294 Short stories by Guy De Maupassant (1850-1893). It is unclear which collection Madeleine is reading.

295 Prince George, Duke of Kent (1902-1942) died in a plane crash in Scotland while on active military duty. Speculation and conspiracy theories continue to surround the cause of the crash.

${ }^{296}$ Published in 1915. See more on the novel and on John Buchan (1875-1940) at The John Buchan Society:

http://www.johnbuchansociety.co.uk/books/49.htm 
know that you are well. We've been on holiday and we spent a day amid white violets, Doggywoggy is here too. The weather was super. Condolences about M. Semaille and we are so sorry about Yolande. I expect that Violette is no longer as happy but what happened was not unexpected. Time will heal everything. I have a primula too. Mine is mauve. We are both in good health and I've got my rambling legs back. I am planning to go on some long walks. Did you pass your exam? And have you been able to find a little time to play the violin? Magui has had news from Aunt Cardénas. She's living out of town and is happy. The chicks are now hens and are starting to lay. I kept a little kitten. She's all black with a white patch on her front. We're calling her Niki. The other Niki is in a farm. He's doing all the work. Love to Granny. Very sorry about Joseph. Pass on my thanks to all our friends". I'm as pleased as punch to have had some news but I felt depressed by it too.

\section{Sunday 30 August}

Mass. C. Put curtains up in the toilet and in the kitchen. They look very sweet and especially so in the kitchen; a countryside or seaside feel to them. Went out at a quarter to midnight to inspect my black-out. Complete and perfect darkness for my bedroom. The same for the toilet. The kitchen is a little bright but it looks out onto a wall 1 metre away and so it doesn't matter. Very pleased with myself. Very windy.

\section{Monday 1 September}

Office. Talked for a while with Denise Pedon. Glimpsed Stella Tiffernan who has made good use of the holiday period to get in with Korbelecky and to oust me from favour. She's now in charge of the mail!! Denise and I have been demoted to the basement. I couldn't give a damn so long as I get paid. What about a pay rise? Rain. BN. Tired out. Saw Jacqueline-who-is-married-youknow. Went to Mme Faure's - lovely, just lovely. Found out that Aunt and I are finished. ([. . . ] am very happy but a little sad too. It's been something of a fixture). She looked as if she knew everything. Yo must have been telling her all sorts about me. Mme Faure as much as said it: “They don't know you at all, and especially not in that milieu”. I egged her on a bit by saying “They think I am feckless". She agrees, of course she does. I had always suspected it to be the case since Orgeval when they said I was too fat because I "stayed too long in bed and didn't do anything" (God knows. At that time I was hardly ever in bed) and they kept making barbed comments about my 'lover' - wherever he was! Yolande is very good at everything and I have always admired her for that. But, the poor thing. What a life she has there.

"Because the road of my life is a road paved with misery" - Ha and her joviality is false, nervous energy. I dropped into the conversation with Mme Faure "I think she might be on drugs when she's as jolly as that" and Mme Faure said: 
"Yes, her eyes are so shiny and so empty". Yolande is a proper little snake. She got me kicked out and I take off my hat to her. It is strange not to feel in the slightest bit saddened by it. Quite the opposite apart than the slight discomfort of breaking an old routine. I have to write to Stepfather and Granny but I am tired out and my eyes are closing. I'll write tomorrow. Granny is very like Yolande but she seems to love me. Is that the case or is it just scheming? Hush, infant, go to beddy-byes. ${ }^{297}$ Your feet are burning up, you can't keep your eyes open. Go wash and then sleepy-byes because tomorrow it's up at 7.15 for exercises. If you hurry along you'll just get to bed by quarter to midnight. So, hurry along. Letter from Jean Soulié about doing the ticket kiosk.

\section{Wednesday 2 Sept}

Whilst doing my exercises this morning I broke the jug in the shape of a Breton woman's head given to me by Yolande. Is it symbolic? I broke the other jug and the teapot - and look now? Especially with the row. Office. Stella Tifferneau was charming. Wrote to Soulié. ${ }^{298}$ Granny. Stepfather. Aunt. BN. Saw Jacqueline Viaux. Saw Mme Maréchal who has had diphtheria. Bought tomatoes, plums, grapes. Queued up with Gaël who was lovely but so utterly spoilt. Unravelled a bit of Mlle Péchegut's jersey. Tired out.

\section{Thursday 3 September}

Got up late. Wrote to Cyla. I won't go to the BN because I haven't the time if I go to the market to try to find some onions [...]. Went to market and bought a blue chrysanthemum which I have just planted. I can feel Autumn on the way. The nights are already that bit colder and the leaves are thinning out on the trees. The chestnut trees are turning rust brown. There are conkers on the ground. The plane trees take on the pale spring tints of trees which are green-gold or red in full leaf. There is a freshness to the air. Terribly hungry. Yesterday I ate half a cabbage, three tomatoes, lettuce, one pound of plums and nearly a kilo of grapes. This morning I finished off the grapes and had lunch $(100 \mathrm{~g}$ of bread and butter) and now, $10 \mathrm{am}$, I am dying of hunger. Ate three crackers and a sugar cube. Is that a good sign? The return of my periods? Office. Stella Tiffernan informed me that I would be put in a concentration camp because of my parents. What next? Saw the young waiter from Louis-Le-Grand. He's got a crush. He thought that Michael was my lover - I made sure he got his facts straight and left him in no doubt with some choice details. And this because we've had lunch together. And if I have dinner with Miss Péchegut I suppose that this

297 'Hush, infant, go to beddy-byes' written in English in the manuscript.

298 Jean Soulier is now spelt Jean Soulié. 
means that I am a lesbian? It seems as if one really has to be a lone wolf ${ }^{299}$ to avoid being said to be this or that. For dinner I had 3 tomatoes, bread, Cancoillotte, grapes, buttered crackers and sugar. Mlle Koch. Very hungry. Sleepy. Tired out. Hungry.

\section{Friday 4 September}

Darned. Had lunch at mine. Ruth came by. Went to the Red Cross. Went by Ruth's (who wasn't there) to pick up some shoes (1 pair) from Cyla.

\section{Saturday 5 September}

Office. Mlle Péchegut came over. Letter from Hélène. Aunt, Mme Desportes. Typed up notes.

\section{Sunday 6 September}

Mass. C. Tired. Migraine. Was on the ticket kiosk for the Festival Chabrier. Jean Soulié was there. Orchestra was a little uncoordinated at first but improved towards the end. Indisposed?

\section{Monday 7 September}

Indisposed. ${ }^{300}$ So happy but terrible pain. Office. Typed notes. Mlle Koch - went off with my shoes because her own are too painful to walk in. Police inspector came to the office about a stolen brass door knob (someone wanted a free litre of wine). Adrienne Monnier's is open again. "Les Plus belles histoires de la peur" ${ }^{301}$ So-So. Spent 50 frs today on nothing out of the ordinary - métro etc. I did spend 25 frs on fruit - but for Berthe who is ill again. The poor thing. Congestion of the lungs. I really must rein in my spending though. Aches and pains, legs feel heavy, appendicitis etc but above all hungry, hungry, HUNGRY. It's only $10.30 \mathrm{pm}$ but I am very tired. I'm off to bed. It's been a chilly day. Autumn is well on its way. Wrote to Aunt, Hélène.

\footnotetext{
299 'lone wolf' written in English in the manuscript.

300 'Indisposed' or just the letters 'I' or ' + I' mean menstruation. Madeleine suffered badly with period pain throughout the Occupation.

${ }^{301}$ Collection of short stories published in 1942 and edited by André Lorde. Contributors included Colette, Pierre Mac Orlan and Jean de la Hire. More on the collection can be read at:

https://www.babelio.com/livres/Andre-de-Lorde-Les-plus-belles-histoiresde-peur/514690
} 


\section{Tuesday 8 September}

+ I. Read "La terre qui Meurt" (René Bazin). ${ }^{302}$ I liked it. "Péguy présenté aux jeunes" (P. Péguy). ${ }^{303}$ Went to see Berthe. The poor love is very low. She has a number of tumours in the lung. She wants to die. She is suffering. She was ill on the 17 August. It seems to me that Aunt would have known when she wrote to me because she wrote to me on the 19th or later. Then I think well maybe she didn't know - oh well! BN. Lovely warm day. Was complimented three times on my looks and my youthfulness. 1: They were betting as to whether I was 19 or 20. 2: Godmother couldn't take her eyes off me finding me very "attractive". 3: Madeleine Fortan confirmed it, saying "You're becoming so beautiful. It's amazing". Also, all the German troops going by on patrol looked at me and I got the feeling that I was 'easy on the eye. ${ }^{304} \mathrm{I}$ inspected myself in the mirror and I don't think that I am beautiful. There are days when I look better. Am I becoming coquettish? Perhaps it's my age? Letter from Voirin. Severine has a little baby Colette two months ago. I didn't know that she was married but maybe she's done what her mother did. Her parents seem to be resigned to it; a beautiful baby can make everything alright - especially here. It wouldn't work back home. M. Duret is much more personable at the office.

\section{Wednesday 9 September}

+ I. Office. BN. Bought some sweetcorn. Went to Necker. Godmother is very poorly. She is delirious and she's in and out of consciousness. Poor love. And she really is suffering. Awful! It seems that I'll get the gold chain bracelet and a ring with a red stone. Mummy will get a silver goblet and a silver napkin ring and Aunt and Yo will get the rest of the jewellery. I will also be getting (apparently) some pans and some crockery. She's not yet dead and everything is being divided up. Poor love. She really makes me sad. Saw Aunt at the hospital. Things aren't good between Yo and Mme Fastier, as I expected. Marcellette's little maid has died. She was so cheerful, so lively! Everyone is dying around me. That's life! - or rather death. Bought some damsons. I'm going over my budget

302 Bazin's novel about peasant life in the Vendée at the turn of the century was published in 1898.

303 Péguy présenté aux jeunes was published in 1941. 'A clear and edifying little study of the evolution of P's religious and patriotic though by P's second son' Richard A. Brooks, Douglas W. Alden (1980) A Critical Bibliography of French Literature Vol 6 (3) (Syracuse: Syracuse University Press), p. 932. The entry is a transcript of a review which appeared in Cahiers de l'Amitié Charles Péguy 2:69, 1948.

304 'easy on the eye' written in English. 
because I am buying fruit but I might as well eat! (there's a philosophy). Had lunch (a good one) with Stella Tifferneau. Paid for it with two kisses.

\section{Thursday 10 Sept}

+. Office. Went to Necker. Godmother won't last the night. Her hands are ice cold. Her forehead is dripping sweat and her right hand and arm are very, very swollen, mottled. Her breathing is hoarse. Her eyes are either closed or rolled back. Her breath is fetid. I can't understand what she says. At first she did not recognise me. Then there was a spark of recognition. "Yo is going to come" "Ah" (indifferent). "Godmother, I really have to go now" "Go, go" (impatience). The only thing she said that made any sense was "You don't understand anything I am telling you". I think that I saw her for the last time today. I'm praying to God that I might just die quickly or slip away in my sleep to not have this long awfulness. Telephoned Aunt. To buck me up, I went mad - fruit and cakes. I'm not upset as such but touching her frozen hand and kissing her on that cold face bathed in sweat, her being all stiff and that foul-smelling breath made me feel nauseous. I wanted to go to the BN but came back here. "la Vie de Beethoven" (Romain Rolland). ${ }^{305}$ Today, the fourth day, ${ }^{306}$ I didn't expect to be ill. I took some aspirin with my coffee. Legs are so very heavy. I think that I would have been in pain. Spotted Ruth at St Louis which proves that Gabrielle has left. What a pain that is. I must watch out. She'll be over here soon. I don't want any of that carry on at mine.

\section{Friday 11 Sept}

Mlle Koch. Godmother Berthe died at 3.30 am. Came back with Yo on the métro from Odéon. We were speaking as if we were merely acquaintances - no intimacy. I have more meaningful conversations with my friends. Went to see "Escadron Blanc". ${ }^{307}$ Good. Read "Marie Chapdelaine" (Louis Hémon). ${ }^{308}$ Hot and suffocating today. Starting with a depression?

${ }^{305}$ Romain Rolland (1866-1944). His study of Beethoven was published in 1903. More on Rolland, humanist, philosopher, essayist and playwright can be found at the Association in his name:

http://www.association-romainrolland.org/

${ }^{306}$ Fourth day of her period.

${ }^{307}$ Italian film which came out in 1941. It was directed by Augusto Genina. See:

http://www.allocine.fr/

3081913 novel written by Louis Hémon (1880-1913). Full text available at Project Gutenberg:

http://www.archive.org/stream/mariachapdelaine04383gut/mrcpd10.txt 


\section{Saturday 12 Sept}

Office. Korbelecky sent a "crude" card to both me and Mlle Pedron. Disgusted. Headache. Very depressed. "Suomi" (?) Bought a big cabbage.

\section{Sunday 13 Sept}

Buried Godmother today (same day 11 years ago she was burying her mother). Divided up the jewellery. Aunt was kind. On the door at the Festival Chabrier. Knitted. Storm.

\section{Monday 14 Sept}

Office. Heat intense and so slept in the afternoon. Heavy. Terrible storm. Waves of water against the the kitchen window. It was like being on the open sea. Mlle Koch and a card from Cyla. Letter from Colette. Mme Piatier came back. "Visite aux américaines" (J. Romains) ${ }^{309}$

\section{Tuesday 15 Sept}

Office. "Prisons et Paradis" (Colette). I really do like to read Colette. It is not so much what she says but how she says it. Real charm. Revised for the exam which means that I snacked continually. I put away nearly a kilo of apples and 3 cubes of sugar. If only I had chewing-gum or a cigarette!! Studying didn't make me do that before. Mlle Cécile Péchegut is going to the Free Zone tomorrow. I feel really pleased wearing the ring and the chain bracelet. I feel very, very pleased actually. It feels strange. I hardly ever wear jewellery. I really want to put perfume on. More and more strange it is. Rain. Autumn is on the way. Enormous grey drapes veil the horizon. When I was doing the cooking today, there was the first steam on the tiles.

\section{Wednesday 16 Sept}

Office. Stella Tifferneau was sacked. Letter from Mme Faure who is coming Sunday. "Montesquieu! (Lawson). Did the washing. Ironed the curtains for the wardrobe and for the toilet. Put the table in the kitchen. Mme Maréchal is 24 years old.

309 Published in 1936 by Flammarion, Visite aux américaines recounts Romain's fascination with America together with his travels across the country in the form of articles he wrote for the French journal L'Intransigeant. See Dominique Viart (1996) Jules Romain et les Ecritures de la simultanéité (Presses Univ. Septentrion), p. 284. 


\section{Thursday 17 Sept}

Office. Studied. Put away the laundry etc. Very nice letter from Aunt. Mlle Koch brought some flowers. Ate some pomegranate.

\section{Friday 18 Sept}

Waited for Hélène who didn't turn up. Knitted. Ate figs. Pneu to Mme Faure. Denise Pedon is 20.

\section{Saturday 19 September}

Office. Wrote to Cyla. Warm sun. The cost of living is rocketing. It is terrifying. It costs 150 francs a week to buy the absolute minimum. With a bit of fruit it costs 200 francs. It is just ridiculous. We've been punished. Apparently, they tried to blow up the Rex, the cinema for the German troops. Sanctions: 116 communists have been shot, there have been lots of deportations. All going-out places have been shut today and tomorrow. Tomorrow the curfew is from three in the afternoon. ${ }^{310}$ Great, won't have to visit Aunt! But I am losing out on $50 \mathrm{fr}$ for the concerts. Oh well, never mind. Went to Mme Paolettés to meet up with Aunt, Yo, and Berthe's nephew and daughter-in-law. The mother and the nephew were utterly stupid about everything. Aunt was furious and she had a right to be. Well! It was a wasted afternoon. As I left I invited Aunt and Yo over. Aunt really wanted to come but then after a sideways glance at Yo to know what to say, she decided no. Yo doesn't forgive me for leading the life that she would so like to lead.

\section{Sunday 20 September}

Mass. A beautiful sunny day but so windy!! I decided to take in my cacti and my geranium now the nights are colder and the dew is heavier. There isn't much difference between the inside and the outside because I always have the windows open. It might only be 1 or 2 degrees difference but that is a lot for a plant. Went on a weevil killing hunt. It takes ages and is boring but at least it is done. Curfew at three oclock. Nothing happened. A window got smashed a little before but I couldn't see anything. A police truck passed by and stopped off to tell the little cobbler to shut his door. Before that a policeman and a member

${ }^{310}$ Forty-six hostages were shot in reprisal for this attack at Mont Valérian, Paris. According to Jacques Delarue, the Germans ordered that $125 \mathrm{Com}-$ munist and Jewish hostages be shot, but because 88 men had been executed the previous month not enough could be found. See: Jacques Delarue (2008), The Gestapo: History of Horror (Barnsley: Frontline Books), p.246. 
of the Garde mobile went by telling us all to get inside. But there's not been a single German patrol. They couldn't care less about us. When there's a curfew they should be coming down the street on motorbikes revolvers in hand, hammering the tarmac with their boots or something so as to scare us all! But alas! In the beginning they were around and we were getting our money's worth but now!! - It is fair to say that this little corner of the rue St Jacques - village St Jacques one could call it - is as calm and as quiet as anything. Time to knit! I swore that I wouldn't do any studying today on a Sunday. There's a scent of autumn in the air but the trees at the Val-de-Grâce are still green. Shut the windows. It's summer but an English summer. The sky is too wan and the sun is too white to be the kind of summer we get here.

\section{Monday 21 Sept}

Rain. Lunch with Ruth at St Louis. She annoys me. Mlle Kamska came back. Boësse. Studied. It really is cold. Mlle Koch came over.

\section{Tuesday 22 Sept}

Office. Did the washing. Went to get the lunch tickets but the staff store is only open mornings. Went to Françoise Boësse's but she wasn't there. All these little gardens around the buildings are so pretty. Took in the cactus and the geranium. I won't even put them outside during the day. Bad memories of what has happened before in spring. Dilys came over because - complete coincidence she wanted to borrow something. This time it's knitting books. Can't she just go buy some? Went to see her room. It's OK. It appears big but it is lacking in taste. She moans that it is difficult to get doing things when Georges is there. I should say! 5 in 2 rooms!! It'd drive me mad. But, well, if it suits them like that. . Jacqueline Piatier locked out of her room. Lent her blanket, towels etc. Raining and cold. Wrote to Hélène.

\section{Wednesday 23 Sept}

Office. Studied but was falling asleep over my book so did some ironing. Jacqueline $\mathrm{P}$ gave me back my cup. She is awfully talkative. 1 and a half hours without stopping. I was going mad by the end because I wanted to go out and get food in. Got some sausage with 3 tickets - carrots, tomatoes. Made myself a nice little meal. Ruth came to give me back the book and to borrow my typewriter. I wasn't keen but refusing would have caused a scene. She wanted to type in my room but only when I wasn't there. What's got into her? I refused point blank of course. That's the second time that she has tried to get into my room when I haven't been here. I don't want that. She tried to get me to feel sympathy for her by talking about the news she got about her grandmother a year ago; news that a friend had not got right. She obviously does not remember that she 
said exactly the same thing in the same words just after Cyla left. She was not banking on me having a good memory. I didn't shower her with sympathy and asked her, as I did the last time, why she had not made use of the Red Cross. I don't know whether it was at that point that she remembered that she had already told me about it. I carried on with what I was doing the whole time that she was there without looking at her once. She tried her ingenious best to find things that would make me get up, leave what I was doing but I went back to it straight away. When she could see that it wasn't working she left with the machine. Straight afterwards it started to pour down. Let's hope that my machine didn't get wet. I've finished my jumper apart from the collar. It is a total success. It suits me very well. If I get the collar right it'll be perfect. I am very pleased with myself.

\section{Thursday 24 Sept}

Wrote to Mme Faure, Mme Desportes. Letter from Hélène. The wind broke one of the stems on my red snapdragons. It's right at the back end of flowering. It's autumn. I only have 24 frs to last me until the end of the month. How annoying. But I will get there maybe. Studied "Montesquieu" (Albert Sorel). ${ }^{311}$ Dilys came. Sylvia was arrested this morning along with all the other Americans. She's at the Jardin d'Acclimatation. Will she go to Vittel or to Compiègne? ${ }^{312}$ Mme Koch didn't come.

\section{Friday 25 Sept}

Office. Studied. Rain. Cold. Wrote to Hélène, Aunt. Letter from Mme Faure.

\section{Saturday 26 Sept}

Office. Studied. Rain. Cold. Scrubbed the floor with wire wool. Got my monthly ration of carrots (one pound) ${ }^{313}$ so that made three (3) big carrots. I was told about 3 arrests in the quartier. They are arresting so many Communists round here. Depressed, bored, listless, no go about me.

${ }^{311}$ First published 1887. The full text of the first edition is available via the Bibliothèque nationale's digital collections: http://gallica.bnf.fr/ark:/12148/bpt6k295180

312 Sylvia Beach was interned at Vittel in France. She was later released. The precise circumstances around her release are unclear, although it is likely that influential contacts played some role.

${ }^{313}$ In the French Madeleine stresses that livre has a feminine gender [une livre]. 


\section{Sunday 27 Sept}

Kamska. Cold rained. Housework. M. and Mme Faure came over. Brought superb dahlias. But I sense some disappointment. Then I understood. They were expecting something more bohemian, a garret with sloping ceiling, books on the floor, socks on the furniture etc. That is exactly why I keep my home very clean. They've seen too many "bohemian rooms" at the Pictures. I hate that. I like things to be clean and beautiful. I like to surround myself with nice things even though I have no money. Ruth came to borrow the typewriter again. Even in the apartment, one can see one's breath.

\section{Monday 28 Sept}

Office. Korbelecky returned. Huge drama because he is investigating Mme Tiffernau. I am ice cold with him because of the card he sent. He told me that Mme $\mathrm{T}$ had had an extremely bad influence on me. I couldn't believe it. I asked him to explain and he told me that I was too young. Me: "Nevertheless I seem to have been able to stave off evil influence". K: "I hope that you stave it off all your life". He smiled an enigmatic smile and disappeared. I've been round and round in circles in my head. I can't find an answer. Real $1^{\text {st }}$ of November type weather. Cold so had myself a cup of tea at 5.30 with crackers and a bunch of grapes. It was mad but I've only got a few bits of chard for this evening. I'm going to be hungry. Went to the Town Hall in the 6th for some lamp fuel for Cécile Péchegut. There wasn't any. Luxembourg turning rust-coloured. The palm trees are still there. Beautiful dahlias, almost no lawns left, beans instead. Did washing. Rain and more rain. Mlle Koch didn't come. Ruth brought the typewriter back when she knew I had a lesson so she could see what my pupil looked like. Sent her packing. She has sewn the button on the cover back on.

\section{Tuesday 29 September}

Office. Kort very cold. Wanted to thaw out without knowing how to without losing all dignity. Rained without stopping. Went for tea to Hélène's. Met her sister, her father, her mother. Her father is very nice. She has a superb violin - and a beautiful Chinese quilt. Finished second pair of yellow socks and started yellow gloves. ${ }^{314}$ In the night I woke crying with cold put on a nightshirt and some wool socks, closed the window and woke up as warm as toast. Got a pneu from Colette.

314 To show solidarity with Jewish citizens forced to wear the Yellow Star as an anti-Semitic means of identification, some brave gentiles wore yellow items of clothing. Here Madeleine pointedly refers to the yellow socks and yellow gloves which she is knitting. Her visit to the Berr family comes shortly after Hélène Berr's father Raymond has been released from Drancy internment camp. 


\section{Wednesday 30 Sept}

Slept very well. Telephoned Dick Ivanoff. Very amusing. So that we could recognise one another I said that I had plaits braided round my head and he told me that he would be wearing a beige overcoat. He has a beautiful voice (my dear!!). ${ }^{315}$ Rain. Going to iron. What happened to the time when I used to start my washing at $15 \mathrm{~h}$ and finish ironing it by 19.30 ? It takes nearly two whole days for it to dry now. I'll go to the office this afternoon to get paid. I'll do my 3 hours there. Aunt sent me a card of Versailles. Office. Very tired. Kamska. Went to Colette's. Rain. Letter from Mlle Koch.

\section{Thursday 1 Oct}

Office. Start of the month abundance: butter, bread and sugar. Very depressed. Went to the "Carnet de Bal" (very, very good but not the sort of thing to cheer one up). Lesson with Dick Ivanoff. Got a note from Monique with some money and some pears. Cold. Letter from Jean Soulié.

\section{Friday 2 Oct}

Office. Police were called to the Centre to throw out a bloke who called Mme Roche-Bernard a "monster" and M. de Retail "Sewer breath". Went to Dyl's for news about Sylvia. Wrote to Cyla, Monique, Mlle Koch. Studied. (I?)

\section{Saturday 3 Oct}

Hôtel-de-Ville. Soulié not there. Ill. Went to Souliés but no reply. Went to "Symphonie Fantastique" Jean-Louis Barrault acts very well.

\section{Sunday 4 Oct}

Villeparisis. Aunt was lovely. Yo is unhappy. She can't get over Jacques. There are no longer any trees along the canal. There was a woman called Gilberte there with her husband and her son Michel. All 3 unpleasant. Granny gave me some lace trim and Aunt gave me 6 plates (for my birthday).

\section{Monday 5 Oct}

Office. Mlle Koch. Ate some disgusting sardines which have given me an upset stomach. Went to Souliés. Stayed for an hour. He is very nice. Saw Jacqueline.

315 'my dear' in English in the text. 


\section{Tuesday 6 Oct}

Office. Ill. Visit from Mlle Bruaud to arrange lessons. Dick. Kamska. Message from Mummy: "Sweetheart, got your June message and Germaine has had a letter from Lulu. Nils is sorry that you've received nothing from his family but hopes that one day you will. Niki has almost grown into a beautiful cat. I have to put her out if I want to work in peace. He sleeps in the armchair. Toutou sleeps on the sofa. We make do with the chairs. Germaine is coming here on holiday for a fortnight. She is managing in the face of adversity. Raoul left her! That was a year ago now. . infidelity. Don't say anything to her sister if she doesn't know. Môme's parents send their very best. Môme hasn't changed and is still where she was. We got some good news about Marguerite. She came back home six months ago and plans to start back working a bit soon. She and all of the family are thinking about you. Her brother got married. I hope that you are all well and that you are less tired. I would be pleased to meet your friends one day soon. Love and thank you from the bottom of my heart to everyone".

\section{Wednesday 7 Oct}

Office.

\section{Thursday 8 Oct}

Mlle Bruaud. Mlle Koch didn't come. Went to Hôtel de Ville to see Soulié who gave me the flyers. Letter from Mme Desportes.

\section{Friday 9 Oct}

Handed out the flyers around the Musée Historique, rue de Sévigné. Looked for some lining. Found some in front of Notre-Dame. Chabert. Kamska. Pneu Jean Soulié.

\section{Saturday 10 Oct}

Office. On the desk at the Bibliothèque Historique, rue de Sévigné. Went to "Charles Gounod" (Delacour) ${ }^{316}$ with Jean Brémaud. Had dinner with him. Hôtel de Ville. Soulié wasn't there.

${ }^{316}$ Possibly a minor play about French composer Charles Gounod (1818-1893). 


\section{Sunday 11 Oct}

Had lunch with Jean Brémaud. "inconnus dans la Maison" starring Raimu. ${ }^{317}$ Had dinner with Jean Brémaud. Jacqueline Piatier left.

\section{Monday 12 Oct}

Office. Mlle Bruaud. No Mlle Koch. Françoise Boësse came to visit.

\section{Tuesday 13 Oct}

Office. Jean B. telephoned. Had lunch at S.B's Went to Châtillon, Bagneux with JB. Splendid weather. Dick. Kamska. Dinner JB, pneu from Mlle Koch. Unhappy.

\section{Wednesday 14 Oct}

Office. Jean telephoned twice. Had lunch with Jean. Went to get flyers with Jean. Went to "Celestine" but there was no performance because Marcelle Génait who was in the lead role was ill. ${ }^{318}$ Fagged out. ${ }^{319}$ Chatted to Madeleine Fortan until $2 \mathrm{am}$. Jacqueline has still not come back. Letter from Mme Koch. Soulié.

\section{Thursday 15 Oct}

Wrote to Aunt, Mme Koch. Office. Went to Hôtel-de-Ville to see Soulié. Dropped in at Jean's. Mlle Koch. Ruth came by apparently and Jacqueline did too I think. Studied.

\section{Friday 16 Oct}

Queued with Jean for sweets and biscuits. Had lunch with Jean. Put posters up at Montmartre. Dick. Kamska. Ruth came over. Mlle Bruant.

3171942 film directed by Henri Decoin and starring actor Raimu (1883-1946), whose real name was Jules-Auguste Muraire.

${ }^{318}$ Pierre Laville wrote an abridged French version of Roja's 1490 text, and it was performed for the first time at the Comédie française in 1942. The mise-en-scène was by Jean Darcante. Agnès Pierron (1977), Maréchal, sa carrière lyonnaise (1960-1975). (Lausanne: L'Age d'homme), p.109.

319 'Fagged out' written in English. 


\section{Saturday 17 Oct}

Office. Lunched with Jean and some friends from Bourges. Went to St Denis "Guignol à Paris". Had dinner with Jean. Opéra-Comique. "Mon Oncle Benjamin." Daft. 320

\section{Sunday 18 Oct}

Went to Chantilly. Drizzly. In the afternoon went to see the Table Ronde, Ory-la-Ville, Les Etangs, Chateau de la Reine Blanche. Back to Paris.

\section{Monday 19 Oct}

Office. Got a note from Jacqueline E. Telephoned Jacqueline E. Message from Mummy. "Condolences to Aimée. Thinking of you on your birthday and of Aunt and the family. Germaine is staying with us for a fortnight's holiday. Everyone is fine. Hugs and kisses. Mummy. 17 August 1942." Letter from Aunt. Mme Piatier. Jacqueline is in hospital. Mlle Koch.

\section{Tuesday 20 Oct}

Office. Errand for Mrs Evans. Had dinner with Jean. "La Celestine". Very good, but crude (dearie me, not for innocent young girls). Letter from Jean. Wrote to Aunt.

\section{Wednesday 21 Oct}

Office. Kamska.

\section{Thursday 22 Oct}

C. office. Mlle Koch. Dick. Went to the Hôtel-de-Ville. Alert. Jean came to dinner. Dilys came.

\section{Friday 23 Oct}

Had lunch with Jean. Mlle Bruaud. Chabert. Kamska. Met up with Paulette Trois-Gros. Got card from Cyla. Bought earrings for Dylis. ${ }^{321}$ Alert.

320 'Daft' written in English.

${ }^{321}$ Dilys misspelt here and in entry of 24th October. 


\section{Saturday 24 Oct}

Office. Had lunch with Jean. His friends came over. Talk at the Hôtel de Sévigné. Rain. Had dinner with Jean. Beautiful moonlight. Dylis's birthday.

\section{Sunday 25 Oct}

Went to Villeparisis. Cold. Yo is very poorly (very serious anaemia).

\section{Monday 26 Oct}

Office. Had lunch with Jean. Broke up with him. I feel very sad and a bit all over the place. Went to Hôtel de Ville. What a void in my life. I'm in terrible pain. Mlle Koch. Dilys and Georges. Wrote to Jean but won't ever send the letter. Raining.

\section{Tuesday 27 Oct}

Office. Knitted. Kamska. Dick. Nothing from Jean. Raining.

\section{Wednesday 28 Oct}

Office. Still nothing from Jean. Went to the Gens des Lettres. Met up with Jean. "Au Pays du Soleil" (variety show). ${ }^{322}$ Stupid. Very music-hall - bad music-hall. ${ }^{323}$ Raining.

\section{Thursday 29 Oct}

+ Office. Sent a pneu to Jean. No Mlle Koch. Jean came for dinner. Raining. I.

\section{Friday 30 Oct}

+ Queued at Jacquin. No sweets. Had lunch with Jean. Went to the office in the afternoon. Dick. Kamska. Raining. Got soaked through to the skin. Letter from Jean Soulié. Chatted with Madeleine Fortan. I.

\section{Saturday 31 Oct}

+ Got up late. Had lunch with Jean. Went to pick up the ticket stubs. Soulié wasn't there. Talk at Hôtel de Sévigné. Turned down by the Ecoles. Raining.

322 An 'Operette marseillaise'. See: https://www.operette-theatremusical.fr/2015/07/04/au-pays-du-soleil/

323 'Bad music-hall' written in English. 
Dinner with Jean. "Promesse à l'Inconnue" (Colisée). ${ }^{324}$ Letter from Mme Faure. I. "Retraite Sentimentale" (Colette).

\section{Sunday 1 Nov}

+ All Saints Day. Got up late. Had dinner with Aunt. Didn't go to grandfather's grave because I had bad Nico. Yo came back with me and stayed until $19 \mathrm{~h}$.

\section{Monday 2 Nov}

+ Had lunch with Jean. Kamska, No Mlle Koch. Raining.

\section{Tuesday 3 Nov}

C. 7.30-12.30 Exam. Essay in French "It is said that "Phèdre" marked the pinnacle of Racinian genius. What is your view?" 2-6 pm. Latin translation. Jean was supposed to come to meet me but was at the studios for "Goupil aux mains rouges" so went for dinner at his place. We had a long talk. Missed the last métro. Raining. Wrote to Mme Faure, Aunt.

\section{Wednesday 4 Nov}

St Charles. Raining. Office. 2 new staff members. - Gilberte X.__? [Frey], Mme Giselle X__ [du Mesnil] and Jacques Dupuis (very nice). I have to work 30 hours a week (damn it). Did washing. Jean came 4-7 pm. Cold. Went to bed at 8.30. Ruth came at $9 \mathrm{pm}$. I don't think that I will see her again for a while. Thank God.

\section{Thursday 5 Nov}

Office. Covered books. Wrote to Jean, Aunt, Cyla, Mme [..?...]. Raining. Went to Dick's but there was someone there and so I came home even though I am sure that today was his lesson. Never mind. I'll go tomorrow and pretend to be surprised.

\section{Friday 6 Nov}

Office. Ironed. Hôtel de Ville. Dick. Kamska.

3241942 French feature film directed by André Berthomieu. For more information see the film entry at:

http://www.unifrance.org/film/6225/promesse-a-1-inconnue 


\section{Saturday 7 Nov}

C. Office but sent home because there was no heating. Talk at the Hôtel de Sévigné. Went to Jean's. Heavy rain. Very cold.

\section{Sunday 8 Nov}

C. Lunch at Jean's Went to Joinville. Dinner with Jean. Weather fine. The Americans have landed in Africa. ${ }^{325}$

\section{Monday 9 Nov}

Washed hair. Weather fine. Very cold. Dilys came. "Invitation à la Valse" (Rosamond Lehmann) ${ }^{326}$ "Chambre d'Hôtel" (Colette)

\section{Tuesday 10 Nov}

Cold. Fine weather. Office. Letter from Mlle Bruaud. Jean came. Dick. Kamska.

\section{Wednesday 11 Nov}

Office. Bachellery "A l'ombre de l'Usine" (?). Had dinner with Jean.

\section{Thursday 12 Nov}

C. Office. Jean came for dinner.

\section{Friday 13 Nov}

Vendryès. Office.

\section{Saturday 14 Nov}

C. Office. Lunch at Jean's. Dinner at Jean's.

325 Operation Torch, the Allied invasion of North Africa, began on 8 November 1942.

326 Rosamond Lehmann (1901-1990) was an English novelist. Her 1932 novel Invitation to the Waltz was one of a number of so-called 'middlebrow' novels by British women writers read by Madeleine during the Occupation. Many of these novels featured women central characters torn between societal convention and new opportunities for social and career mobility after the political successes of first-wave feminism in the first two decades of the Twentieth century. See Nicola Humble's 2001 monograph The Feminine Middlebrow Novel 1920s to 1950s: Class, Domesticity and Bohemianism. 


\section{Sunday 15 Nov}

Villeparisis.

\section{Monday 16 Nov}

Office. Lunch with Jean. "Une Note de Musique” (Rosamond Lehmann). Made me feel depressed.

\section{Tuesday 17 Nov}

Office. Dick. Kamska.

\section{Wednesday 18 Nov}

Office. Bachellery. Hôtel de Ville. Had lunch with Jean. Had dinner with Mme Faure. Chicken, chips. Ill. Went to Jean's to get some pills for my digestion. Alert 8.30-9 pm. Got some news from Mummy. "20 Oct. Darling. I hope that Granny has recovered well from her operation. Germaine spent 3 weeks with us and is doing well. I am pleased that you had some news from Paul. We haven't yet had any news from Cyla. We will be glad of it when it does arrive. Here all is well. Health is good. Jeanne also has a little cat. She calls it Fluff. The mice are no longer having a free run. I was given some new plants for the rockery and did I tell you that there are 2 apple trees in the garden behind the house? Since Germaine's stay I have been getting used to my dentures. Kisses. Be well. Mummy".

\section{Thursday 19 Nov}

C. Office all day. Had dinner with Jean. "Dernier Atout" ${ }^{327}$ Missed the last métro.

\section{Friday 20 Nov}

Vendryès. Office. No Dick.

\section{Saturday 21 Nov}

C. Office. Lunch with Jean. Dinner with Jean.

${ }^{327}$ A 1942 film thriller by Jacques Becker. 


\section{Sunday 22 Nov}

C. Showers. Lunch with Jean. Went to the Jardin des Plantes. ${ }^{328}$ Very cold. Dinner with Jean. Alert 9-10 pm.

\section{Monday 23 Nov}

Office. Lunch with Jean.

\section{Tuesday 24 Nov}

Office. Lunch with Jean. Dick (paid). Kamska.

\section{Wednesday 25 Nov}

C. Office. Chabert. Bachellery. Jean came to dinner. Jean Soulié telephoned.

\section{Thursday 26 Nov}

C. Office all day. Hôtel de Ville. Met Jean. Dined with Jean.

\section{Friday 27 Nov}

Vendryès. Mme Péchegut bought me a coffee and cake. Office. Dick.

\section{Saturday 28 Nov}

C. Office. Had lunch with Jean. Distributed posters. Bought "le Grand Meaulnes" 329 for Yo's birthday. Met up with Dilys. [...] nobody from the camp. Pneu to and from Aunt. Had dinner with Jean. He wants me to become his mistress. $\underline{\mathrm{NO}}$

\section{Sunday 29 Nov}

Missed the 10.25 train. Took the midday one. Villeparisis. "Alerte aux Blancs" (Stupid).

${ }^{328}$ Le Jardin des Plantes is a botanical garden of exotic plants in the 5th arrondissement of Paris.

329 Written by Alain Fournier (1886-1914). Fournier was killed in action in September 1914. 


\section{Monday 30 Nov}

St André. Yolande is 24 years old. Office. Jacques Dupuis is leaving. Had lunch with Jean (very distant) Handed out posters. Had hot water. Washed. Less cold. Pauphilet. Chabert. Rue St Jacques [...].

\section{Tuesday 1 Dec}

Office. Kort was ill. Michael spoke to me at midday (he said that he loved me). Did the washing. I'm at a dead end with Jean. Do I love him? Do I not love him? Saw Françoise Boësse. Dick. Darned. I've had enough. My head is spinning with all these thoughts. Not very cold. Saw some little dolls - was going to buy myself one but they were 100 frs each!! They'd be $1 / \%$ back home. No, no, no.

\section{Wednesday 2 Dec}

C. Office. Bachellery. Hôtel de Ville. Went to Jean's but wasn't there so waited $1 / 4$ hour. Had dinner with Jean (a slice of roast pork).

\section{Thursday 3 Dec}

Office all day. Tea with Dilys. Food supplies are better this winter than last because there are still some carrots, turnips (with tickets) and without tickets there's lettuce, beetroot. Jean told me that he was disappointed in my journal because I only talk about trivia. That's right because I am wary of prying eyes like his for example. Got card from Cyla. Dilys came to listen to the TSF.

\section{Friday 4 Dec}

+ Queued for biscuits at Samaritaine with Jean. Office (was late and got a dressing down from Korbelecky. Ironed. Dinner with Jean at Le Pajolec and La Saugette. Nice. Jean missed his connection. I

\section{Saturday 5 Dec}

+ Office. Lunch with Jean. Tea with Mme Desportes. Dinner with Jean. I

\section{Sunday 6 Dec}

+ Lesson with Dick. Read "Undine" (Fouqué). ${ }^{330}$ Read "Amour en Amérique" (?) Darned. Dilys came over to listen to the radio. Great Sunday. Had a good rest. Quiet. I

${ }^{330}$ Fairytale by Friedrich de la Motte Fouqué (1777-1843) published in 1811. 


\section{Monday 7 Dec}

+ Office. Lunch with Jean. Lesson Pauphilet. Françoise Boësse came for a cup of tea (returned books) Went to Chabert's but he wasn't there because he was called up on Saturday with the other Rumanians. Ruth came over. Pneu from Hélène Koch. Wrote to Aunt, Cyla, Hélène Berr, Hélène Koch. No money to buy Christmas presents but I have to. What will I do? I

\section{Tuesday 8 Dec}

Office. Slight stomach ache. Had lunch with Jean. Argued with him. I stop him from doing anything and that makes him really angry. How many days has this been going on for now? He is secure in his certainty that the next time he asks me to be his mistress I will agree and all the while I am preparing never to see him again. I no longer love him. And I feel that deep down. It has lasted two months. The longest relationship I've had. I had one in ' 40 - I no longer remember his name even, Michel perhaps or Marcel? He came out with "You're married it seems!" First I'd heard of it but I said "yes I am" just to get rid of him. It worked. Thank God for that. Where does this nonsense come from? Françoise told me yesterday that I was English and that my father was an engineer. What next!! I'm looking forward to the sequel. I'll probably end up with kids. That'll get people talking given that I live alone. Funny how people think that one can't live without physical love. I mustn't be normal. Thought back over my boyfriends. It's awful. I can't remember their names: -

Friday ? Dec 1937: Peter Simpson 25. 1st kiss July 1938: 1st date with ?? (35 yr old Bulgarian)

March 1940: Michael? Marcel? Maurice? 26 years old. Artist [looked through the archives - he was called Marcel Legros]

July 1941: Jean Peignot 35 (?)

October/December 1942 Jean Brémaud 36.

Huge unrequited love for Kachinsky - Spring 1938

A bit of flirting with Roger August 1940

Was kissed on the train by a Greek on 1 April 1938

Michael falling in love with me, winter 1940-41

The soap ration has been cut by half - what a pain. Bought Néméton, the Druid studies review. Quite strange it is. Darned. I'm hungry. It isn't very cold. Jean came but I wasn't here. Lesson with Dick. Alert 7.10-8.15 pm. One more around midnight but didn't hear it because I was asleep.

\section{Wednesday 9 Dec}

Cold. Office. Kort was in a good mood (about time!) Chabert hasn't been called up. Bachellery. Renewed my readership membership at Adrienne Monnier's 
Saw Dilys who was not happy to see me. Had dinner at Jean's. Went to "La Corrida" at the Théâtre Charles de Rochefort with Charles de Rochefort and Mary Grant. Only the woman acted well. Cold. "Ondine" (Giraudoux). ${ }^{331}$

\section{Thursday 10 Dec}

In the office all day. "Poussière" (Rosamond Lehmann) ${ }^{332}$ Lesson with Gilberte Frey. Chabert. Letter to Hélène Koch. Mme Faure. Wrote H. Koch, Jean. Less cold. Saw a quarter moon and a shooting star. Restless, happy but pale and drawn. I need 3 days of absolute rest. Studied Welsh.

\section{Friday 11 Dec}

Got up at $9 \mathrm{am}$. The sun looked as if it was on fire and then it went grey. Vendryès 10-12.15. Office. Finished "Poussière". It made me depressed. Met Mlle Bruand. Dick. Nothing to eat. Made pancakes but with no eggs or milk. I make them better than Jean does. Bought a box of chocolates for 130 frs (in 1938 the same box was 13 frs) At the office, Kort and Duret were flirting with me. Am I attractive then? To be completely honest I can't see anyone want to love me. I am fearful of living life to the full. I like to feel safe. Let's hope that I find a good husband who can give me children, a beautiful house a beautiful garden. I really do miss a garden. Oh I wish I could go back!!!

\section{Saturday 12 Dec}

C. Office. Pneu from Mme Faure. Lunch with Jean. "Siegfried et le Limousin" (Giraudoux). Dinner with Jean. Folies Bergères.

\section{Sunday 13 Dec}

Split with Jean. Cried for two hours about him. Came home and went to bed. Read "Crime du [...] Chamois" (Wells) Slept. Read Giraudoux. Only had noodles to eat. Spent 40 frs on sweets and cake to console me! Dilys came to listen to the news.

\section{Monday 14 Dec}

Office. Pauphilet. Lesson Mlle Koch. Glberte. Chabert. "Si le Grain ne meure" (Gide). ${ }^{333}$ I think Jean was play acting yesterday and I took him seriously. He

${ }^{331}$ Giraudoux's play Ondine was based on Fouqués Undine, which Madeleine had read the previous week.

${ }_{332}$ Dusty Answer was first published in 1927.

${ }^{333}$ Si le Grain ne meurt was a 1924 autobiography by French writer André Gide (1869-1971). Madeleine misspells the title in her entry. 
must be very annoyed. That charitable thought has comforted me a lot. Saw Hélène Berr, Françoise Boësse, Madeleine Lavelle. Terribly hungry. Bought $475 \mathrm{~g}$ of honey for $105 \mathrm{fr}$. Thinking about the winter.

\section{Tuesday 15 Dec}

Office. Darned. Lesson with Dick (got paid). Ate mussels.

\section{Wednesday 16 Dec}

Office. Welsh. Breton. Bachellery 2-4. Saw Paulette Trois-Gros. "L'Heure des Adieux" (German film, so-so) ${ }^{334}$ with Giselle de Mesnil. Had dinner with her. Wrote to Aunt.

\section{Thursday 17 Dec}

St Yolande. Office all day. Kort in a bad mood. Typed from the book I borrowed off Bachellery until $1.30 \mathrm{am}$. Letter from Hélène Berr.

\section{Friday 18 Dec}

Irish, Welsh Vendryès. Office. Lesson with Dick. Typed book. I've been so much happier and lively since I've stopped seeing Jean. I see now that subconsciously I didn't like him. Raining. Mild.

\section{Saturday $19 \mathrm{Dec}$}

Office. Did the tickets rue de Sévigné. Saw Dilys on the rue St Jacques. Went to Confession. Had tea with Françoise Boësse (she gave me potatoes and tickets for potatoes). "Katrina" (Sally Salminen), 335 "Derrière les Barbelés" (Louis Walter). ${ }^{336}$ Letter from Aunt.

${ }^{334}$ A 1941 German film directed by Helmut Käutner. For more information on plot and cast see:

http://www.telerama.fr/cinema/films/l-heure-des-adieux,447575.php

${ }^{335} 1936$ novel by Finnish author Sally Salminen (1906-1976).

${ }^{336} 1942$ account of the author's captivity as a POW between 1940 and 1941. Read more about Louis Walter and his testimony at the website and database EGO 39-45, Écrits de Guerre et d'Occupation hosted at: http://www.ego.1939-1945.crhq.cnrs.fr/recherche/detail_ouv.php?id_ ouvrage $=198$ 


\section{Sunday 20 Dec}

Sun. Mass. Put my hair up. Bought some holly and decorated Mum's picture with it. Alert between 12 and $12.50 \mathrm{am}$. Worked. Ill. Mad. Fortan came to talk.

\section{Monday 21 Dec}

Office. Ill (Gastroenteritis?). Wrote to Hélène Berr. Lesson with Dick. Letter Mme Koch stopping lessons with Hélène. Letter Mme Yvonne Disner. "la Couronne" (Sigrid Undset) ${ }^{337}$ Worked. Cold.

\section{Tuesday 22 Dec}

Office. Giselle warned me that Chantal said that Kort wants to sack me. I don't believe her. "La Maison près du Cimetière" (Morgin De-Kean). Not bad. Torrential rain. Lesson with Gilberte. Cold. Worked.

\section{Wednesday 23 Dec}

Office. "La Femme" (Sigrid Undset). Welsh with Bachellery. Tea with Mme Desportes. Met a prof of Parasitology. Package from Cyla, biscuits, sweets. "Les Petites âmes" (Géraldy). Rain.

\section{Thursday 24 Dec}

Card from Chantilly. "Thoughts of you - Jean". What does he want me to do with his thoughts? Got up late. Lesson with Dick. Read. Did shopping. Took the radio over to Dilys. Stayed for dinner. Dilys gave me some powders.

\section{Friday 25 Dec}

Christmas. Villeparisis. Aimée, Huguette, M. Labine were there. Went out with Huguette. So true! For nearly 18 years she has been scared stiff of everything and lethargic. Aunt is worried that Yo has something on the lung. I don't think she has.

\section{Saturday 26 Dec}

Got up late. Card from Mme Faure. Pneu from Gisèle du Mesnil inviting me for Christmas Day eve!! Had some bacon (40 grams) Made an omelette with fat and potatoes (with my 2 eggs allowance for December). "Le Mariage de

337 Sigrid Undset (1882-1948) was a Norwegian novelist. She won the Nobel prize for literature in 1928. 
Chiffon"338 with Cécile Péchegut. Got some Oxo and some cake with her at Marcuisot. "La Mort du Cygne" with Madeleine Fortan. Very good. It was well heated there.

\section{Sunday 27 Dec}

Got up late. Mass. Read. Sorted letters etc. Read Mummy's letters again. She is so adorable, so simple, so kind - all the qualities! My sweet Mummy. Made some bread (a little hard and it didn't have any yeast but very successful!!!). I think that I would cook quite well if I had the time and the utensils. A little bowl (?) from Ruth. What can I buy her? Wrote to Cyla, Mme Faure, Yvonne Zéau. - Mad F came over to talk for 2 hours. Got the radio back. Tired. It's really good in this apartment. God, I am hungry!

\section{Monday 28 Dec}

Office. "La Croix" (3rd vol of "Christine Lavransdatter" 339 [Sigrid Undset]). Jean came. Lesson (?) Chabert. Cold.

\section{Tuesday 29 Dec}

Card from Cyla. Office all day. Had lunch with Jean. Tea with Hélène Berr. "Deirdre of the Sorrows" (John Synge). ${ }^{340}$ Snow.

\section{Wednesday 30 Dec}

Got up late. Had lunch with Jean. Got the beginning of the explanation but had to go to the office. Went to the Red Cross. Snow. Lesson with Chabert. Three of his friends came.

\section{Thursday 31 December}

Got up late. Went to Dick's but not there. Letter from Mme Faure. Pneu from Yvonne Disner with ticket. Snowing. Did the grocery shopping. It takes so

${ }^{338} 1942$ film directed by Claude Autant-Lara. This was an adaptation of an 1894 novel by French woman novelist Gyp - a.k.a. Sybille Riquetti de Mirabeau (1849-1932). There is very little information about Gyp other than that available at a French wikipedia entry: https://fr.wikipedia.org/wiki/Gyp\#Liens_externes

339 Kristin Lavransdatter. 'Christine' appears to be a misspelling.

${ }^{340}$ Irish playwright John Synge (1871-1909) published Deidre of the Sorrows in 1910. See René Agostini's article on Synge's 'problem play': http://www.persee.fr/doc/irlan_0183-973x_1988_num_13_1_2485 
long and I spend so much money!!! Draught-proofed my room. Wearing ankle socks still. Put on my straw weave shoes because the wooden soles don't grip in the snow. Went to 'The Winter Circus' with the same tigers that injured Gina Manès - real beasts. Broke up with Jean. Went to see Dilys $11.45 \mathrm{pm}$ for the New Year. Came back to mine at 12.15

Resolutions: $1 / 4$ hour of physical exercise every working day (ie: not Sunday) 1 hour of mending and darning etc, housework every day 10 hours thesis a week. 
